\title{
Multifunctionality in Mediterranean landscapes - past and future
}

\author{
Teresa Pinto-Correia ${ }^{\#}$ and Willem Vos ${ }^{\# \#}$
}

\begin{abstract}
During past decades many of the traditional multifunctional Mediterranean landscapes with their typical complexes of agro-, silvo- and pastoral components changed thoroughly. Nowadays only few of them are still vital. Their complex farming systems secure at the same time a multitude of other functions than just agricultural production, such as support for recreation, amenity, cultural identity, preservation of natural resources and environmental quality. Some of these unique, old Mediterranean landscapes are discussed. They cover a broad range from near-tonature high mountain landscapes and terraced small-scale submediterranean polyculture landscapes to dry Mediterranean agro-silvo-pastoral landscapes. All these are changing, either spontaneously due to changing socio-economic and cultural conditions, or as a result of conscious policies, with the Common Agricultural Policy as a main driver. Even measures created to support specific traditional land uses and their landscapes are often not successful as they focus on only a part of the system. These policies and measures will not hold the valuable traditional systems from collapsing and subsequent vanishing. Some other policy instruments, such as those in forestry, are not meant to support them, but to transform them in favour of new monofunctionality. New strategies and instruments ought to deal with these multifunctional landscapes in a more integrated way, if some of them are to be maintained or transformed into others with similar qualities.
\end{abstract}

Key-words: landscape; multifunctionality; Mediterranean; CAP; agro-silvo-pastoral; agri-environmental

\section{Introduction}

It is generally known that Mediterranean landscapes result from a very long human history that interacts with an extremely varied physiography, soil and climate (Arino and Roque 2000; Naveh 1991; 1998). For at least 500,000 years man used nature as a bran-tub, and moved with nature as a clever predator. During this long prerural period man genetically evolved together with nature, and in doing so, he influenced speciation and ecotypic specialization. The co-evolution of man and nature was so profound that in many cases human impacts can hardly be distinguished from natural ones (e.g. Grove and Rackham 2001). From the Neolithic agricultural

\footnotetext{
\# Dept. Planeamento Biofísico e Paisagístico, Universidade de Évora, Colégio Luis Verney, 7000 Évora, Portugal. E-mail: mtpc@uevora.pt

\#\# Wageningen University and Research Centre. Correspondence: Molenstraat 9, 6701 DM

Wageningen, The Netherlands. E-mail: vos.vis@tiscali.nl
} 
revolution till the Renaissance urban emancipation, many of the main land-use changes started in the Mediterranean world (farming, living in cities, sailing, trade, colonization, town and country planning, civil and rural technology, etc.). It altogether created a unique diversity: cultural, ecological and visual (e.g. Grove and Rackham 2001; Moreno and Oechel 1995; Valaoras 1997).

Site-specific farming strategies, developed to feed a growing population in difficult and often unreliable environments, contributed positively to this diversity. With trial and error, through hunger and pests, complex and vulnerable land-use systems developed that focused on continuity of production and avoidance of risks by taking maximum profit from the inter-annual climatic fluctuations. This was for instance achieved by maintaining dynamic nutrient equilibriums, complete use of natural resources, closing of mineral and water cycles (and thus low inputs) and multifunctionality at field, farm and landscape levels.

Many systems were based on interactions within the ancient trinity of trees (silva), grazed shrubs, herbs and grasses (saltus) and cultivation (ager) (Joffre, Hubert and Meuret 1991), and interactions with artefacts that in various combinations of scale and intensity took a prominent position (e.g. Naveh 1998). The latter consisted of natural materials, and their integration in nature for centuries or millennia, forming suitable wildlife habitats, made nature-culture discontinuities in many cases irrelevant.

The high value of these traditional landscapes with their characteristic patterns, high biodiversity and rich history has been recognized for years (Vos and Stortelder 1992; Vos, Austad and Pinto-Correia 1993; Vos and Klijn 2000; Council of Europe 2000; Junta de Andalucia 2001; Baldeschi 2000). Nevertheless, most of them vanished or are threatened by what Naveh calls a neotechnological degradation. This results from intensification and upscaling, with as basic principles: increased labour productivity and decreased uncertainties. And thus, less natural dynamics: everything under control and everywhere the same, in a global standardization trend. This may easily cause the neglect of natural restrictions and the disturbance of previous equilibriums. Subsequently, in many cases the system changes into a more simple stage, without the qualities described above. Other landscapes vanish by agricultural extensification, marginalization and abandonment. Similar impacts affect traditional rural landscapes all over Europe (Austad 2000; Council of Europe 2000; Green and Vos 2001).

While these valued cultural landscapes gradually decay, new demands by our 'shopping society' enlarge the interests of the same landscapes. They provide high multifunctionality, the combined outputs of the production functions of agriculture and forestry with those of the regulation functions of ecosystems and the information functions of nature, geology, history, scenery etc. In doing so, they comprise combinations of food production, housing, recreation, water management, nature management and culture conservation within one and the same land-use system (Klijn and Vos 2000). Multifunctionality at landscape level integrates the various functions in the same space (Vos and Hoogendoorn 2000; Brandt and Vejre 2004). It is highest when maintained simultaneously at various levels (field, farm and landscape), as in many traditional land-use systems (Vos, Austad and Pinto-Correia 1993; Vos and Klijn 2000). Recent strategies for landscape management focus on multifunctionality at various levels too (Vos and Hoogendoorn 2000; Antrop 2000; Council of Europe 2000; Wascher 2000).

As the need to support these valued landscapes gradually became acknowledged, instruments were developed to safeguard them. Some of the latter are part of culturalheritage protection and nature-conservation policies, but the main instruments are 
those of agricultural policy, since the role of farming is in general crucial in these landscapes. These measures are however not always successful or, at least, their sustainability is doubtful. In the meantime the remaining vital fragments of traditional landscapes further degrade. In fact, they simplify and may end as ruins or empty façades: abandoned or with alienated functions.

Main questions for future planning and management are, which of these landscapes can be sustainably preserved on the long term, which changes they still have to face, which functions they may provide and which measures may be applied. As a contribution to understanding the complexity and the multiple management questions we will discuss some examples of the traditional multifunctionality of:

- Mediterranean-montane climate mountains: pastoral and forestry landscapes with transhumance

- Mediterranean-Atlantic climate mountains: small-scale mixed farming landscapes with lameiros in Northeastern Portugal

- Mediterranean-submediterranean climate hills: coltura promiscua landscapes with métayage (mezzadria) in central Italy

- Submediterranean climate hills and mountains: chestnut-grove landscapes in France and Italy

- Mediterranean-continental climate plains: landscapes with montados and dehesas in Southern Portugal and Spain

Except for their multifunctionality at different levels, these landscapes also have in common that they are rapidly changing and - in many cases - are vanishing. They therefore deserve special attention for what is going on and for the challenges of their present and future management.

\section{A synoptic landscape geography}

Mediterranean landscapes display the different ways multifunctionality developed under different conditions. This causes similarities within the same bioclimatological and physiographical zone despite of different histories and cultures. Main differentiating factors of the landscapes of Mediterranean Europe are the altitudinal zoning and the distance to the sea, and thus the subdivision in bioclimatological regions (Figure 1), together with the physiography (Figure 2). The latter may be subdivided at the highest level into: (1) Coastal plains and deltas, (2) River flats, (3) lowlands and large river basins, (4) Hills and low mountain-chains, (5) Inland plains, (6) High mountain-chains. 


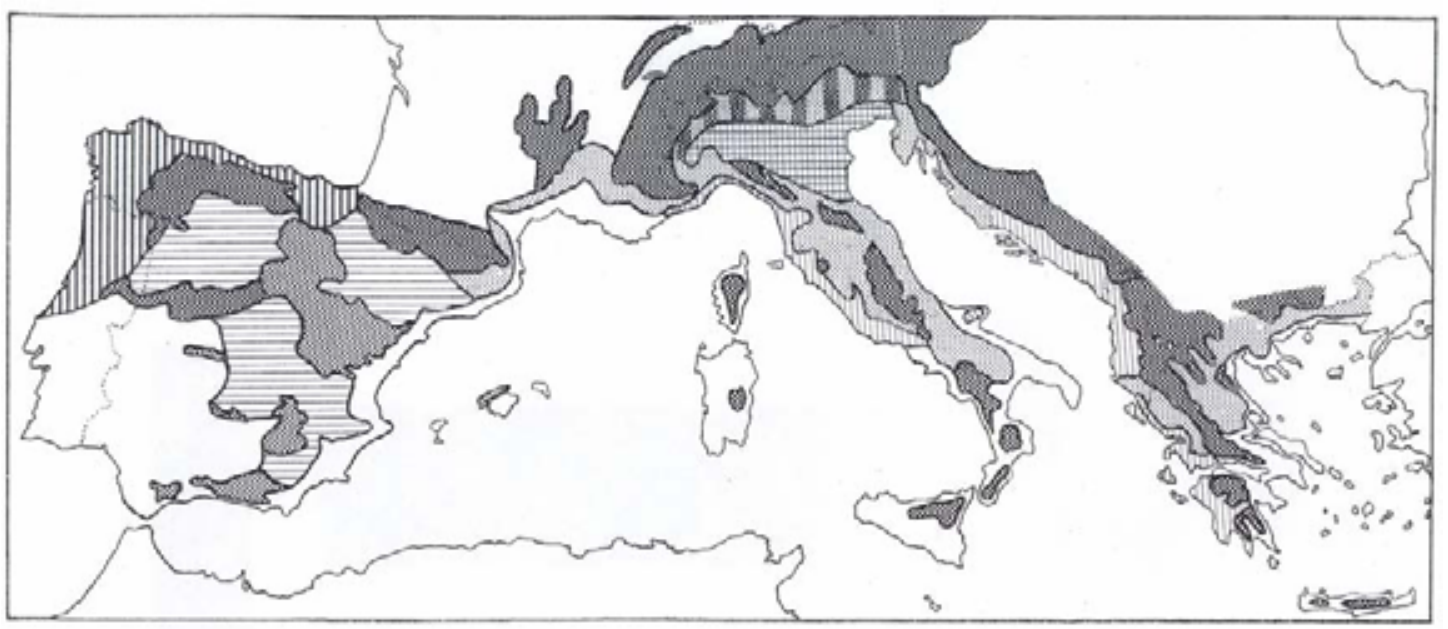

Dry season of more than 2 months: Dry season of less than 2 months:

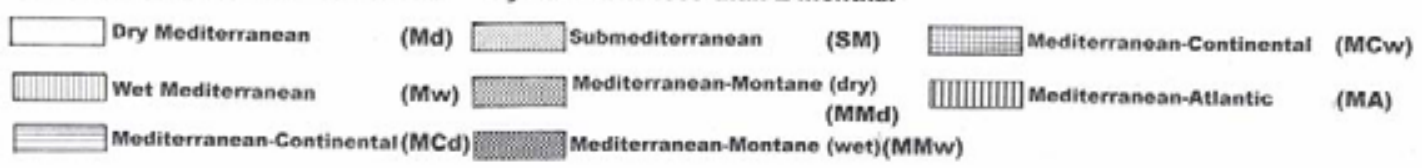

\begin{tabular}{|c|c|c|c|c|c|}
\hline & & $\begin{array}{l}\text { Precipitation } \\
\text { Summer arbught }\end{array}$ & Mean amous P & $\begin{array}{l}\text { Temperature } \\
\text { Warmest moneh } \\
\text { Mesn T }\end{array}$ & $\begin{array}{l}\text { Coidest month } \\
\text { Mean } T\end{array}$ \\
\hline Medaterranean Idm) & ma & $>2$ months & $<100 \mathrm{~mm}$ & $>222^{*} \mathrm{C}$ & 360 \\
\hline $\begin{array}{l}\text { Medinetranean (wet) } \\
\text { Medinerranean Continentat }\end{array}$ & ${ }_{M N}^{\text {Mo }}$ & $\begin{array}{l}>2 \text { months } \\
\text { > } 2 \text { months }\end{array}$ & $\begin{array}{l}>500 \mathrm{~mm} \\
<500 \mathrm{~mm}\end{array}$ & $>22{ }^{\circ} c$ & $\begin{array}{l}36 \% \\
46^{\circ} \mathrm{c} \\
\mathrm{c}\end{array}$ \\
\hline Meseseranezn-Continental & new & $<2$ months & $>500 \mathrm{~mm}$ & $>227 \mathrm{c}$ & $0.2^{2} \mathrm{c}$ \\
\hline Submediterranem & $\sin$ & $<2$ months & $>300 \mathrm{~mm}$ & $=22 \%$ & $2.6 * 6$ \\
\hline Mediterranean Mentane (dry) & Aand & $\leqslant 2$ months & $<000 \mathrm{~mm}$ & $<22=\mathrm{c}$ & $<2 c$ \\
\hline Mediterranean Montame (wet) & MAN & $<2$ months & $>800 \mathrm{~mm}$ & $\operatorname{len} c$ & $<\dot{r} \mathrm{c}$ \\
\hline Mediterranean-Ablantic & MA & $<2$ months & $>800 \mathrm{~mm}$ & $<22^{\circ} \mathrm{c}$ & $36^{\circ} \mathrm{C}$ \\
\hline
\end{tabular}

Figure 1. Mediterranean climate types (carthographic data: Steinhauser 1970; Thran and Broekhuizen 1965)

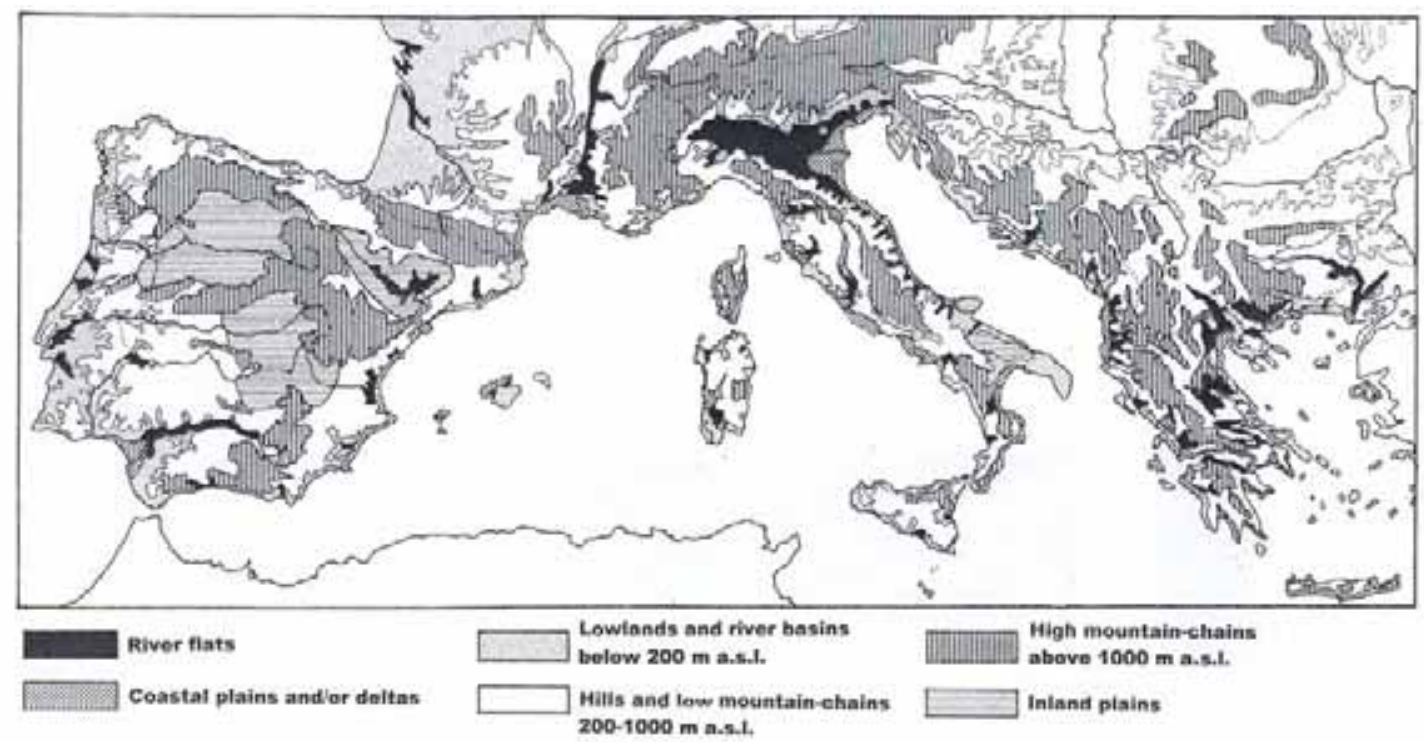

Figure 2. Main physiographic landscapes

Throughout prehistory and history, land use differentiated these units within the possibilities offered by available techniques, labour and financial, social and political conditions. A growing population caused a complete use of the available space and created sometimes very complex and diversified landscape mosaics. 


\section{Mediterranean mountains}

Their physical and socio-economic conditions made the Mediterranean mountains, especially those that rise above ca $1000 \mathrm{~m}$ above sea level, poor, isolated, backward, rough and wild. These areas above the milder submediterranean zone, comprise altogether a substantial part of Southern Europe (Figure 3). Many mountains were so unattractive that they were uninhabited until far in the 19th century (see e.g. Braudel 1966; McNeill 1992). And if they were inhabited, there mostly was a structural unemployment, which fed the markets with surplus labour, such as in lowlands and plains that depended on seasonal labour by mountain folk. Apart from the seasonal herding, it could be the harvest of vines and olives in autumn-winter, planting of rice in spring, cereal planting in autumn, weeding and hoeing in spring, preparing the vineyards in winter and sugar harvests in Southern Spain in February and March. As 'free entrepreneurs', mountain people also sold burned chestnuts, ice and charcoal in the cities. Other solutions were the entry into foreign armies or monasteries, smuggling and robbery, and temporary or permanent emigration. Still, many mountains remained poor until today, like those of Northwestern Iberia, and many of them have been abandoned in past decades, as several times before.

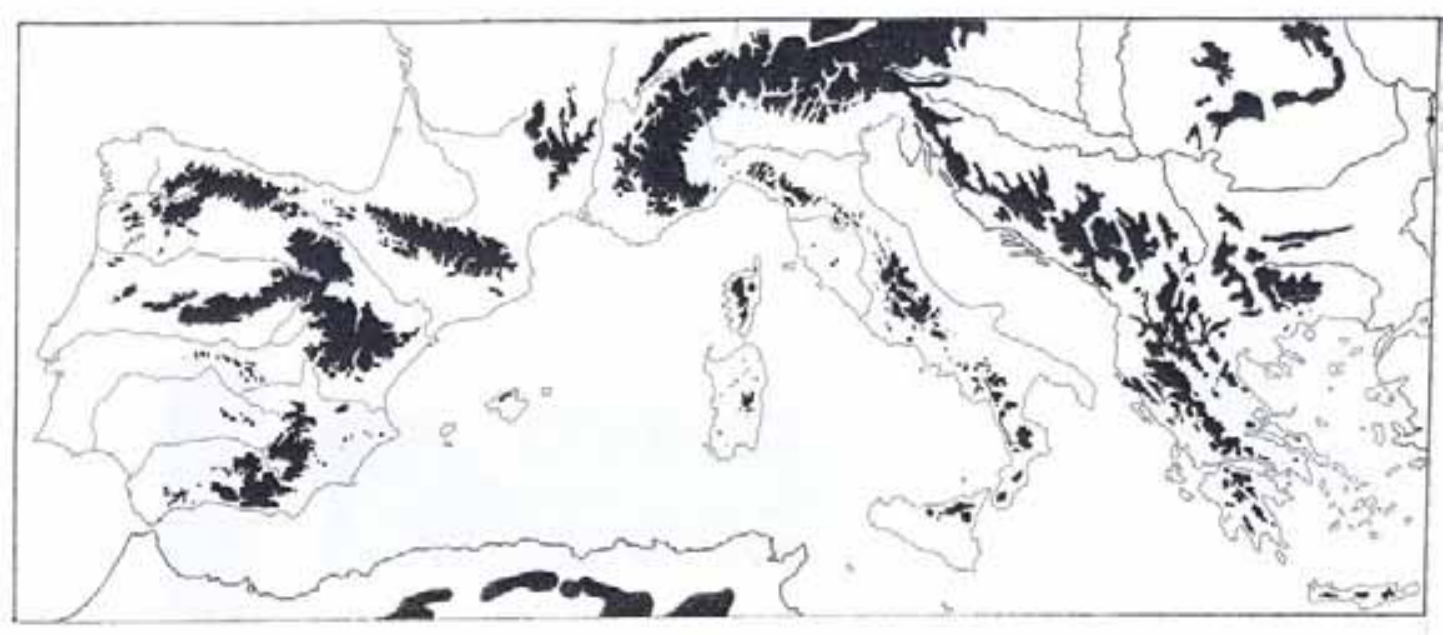

Figure 3. Southern Europe above $1000 \mathrm{~m}$ above sea level

The Mediterranean mountains always had the problem of the tension between the low carrying capacity of the environment and the population pressure. Overpopulation frequently induced land clearings on inappropriate sites. Underpopulation could cause abandonment or relaxation of land use, resulting in the vanishing of the most specific attributes of landscape identities (land uses, paths, irrigation works, walls, farms and even whole villages, together with culture-bound plants and wildlife). In either event landscape could be heavily affected (McNeill 1992).

Land-use practices easily shifted: forest massifs became shepherd massifs or peasant massifs, and sometimes peasant massifs became shepherd massifs and vice versa. Some examples: In the 19th and early 20th century the deforestation of the Pindus (Greece) in favour of pastoralism was so great that even in the 1980s the cultivated area amounted to only about 3 percent of the area of a century before. Southern Italy had a similar development in the first half of the 20th century in favour of cereals, due to Mussolini's 'Battle for Wheat'. Also Spain lost most of its forests in the 19th and beginning of the 20th century. However, everywhere in the mountains the increment of forestland was enormous after World War II, both by planting of conifers and by regeneration after abandonment. 
Mediterranean mountain forests are diverse (Beckel 1995) and host the largest predating mammals of Europe (brown bear, wolf, lynx). Some forest economies are: livestock breeding with forest grazing, chestnut-fruit production, timber, shortwood and fuel-wood production and charcoal burning. Hunting and gathering of mushrooms and truffles were normal practices.

A very specific mountain business was the gathering and trade of snow and ice, which has a long history. Many high mountains around the Mediterranean have a snow cover during several months every year. Historical information shows that from the 15th century on ice and snow have been used in cities like Madrid, Lisbon, Istanbul, Tripoli, Cairo, Malta, Naples, Catania and Rome (Braudel 1966).

Wood has always been used as fuel and the cutting of trees for timber and pales began far back in prehistory. But although Hesiod described already around $700 \mathrm{BC}$ the production of timber on his Boeotian farm (Meiggs 1982), the integration of forests in farming systems especially progressed since the Middle Ages. Before the 13th century, except for incidental timber yields, main forest functions were to serve as hunting grounds for noblemen, above all for fur and hides, and as foraging area for farmers' pigs. Where the latter was very intensive, it could strongly affect forest rejuvenation and nutrient supply, especially if it was combined with gathering of litter and sods for stables and subsequent fertilizing of fields (Vos and Stortelder 1992). From high Middle Ages on, under the guidance of monasteries, forest multifunctionality ever more complemented the farming results. The tree, shrub and field layers and even the forest floors were harvested for firewood, timber, pales, fodder for livestock, litter and sods for stables, and fruits, mushrooms and game as human food (Vos, Austad and Pinto-Correia 1993). This planned exploitation and management of woods and forests resulted in a broad spectrum of forest types: from closed-canopy forests to open savannas, from near-to-nature forests to artificial plantations and from cycles of only a couple of years to cycles of several hundreds of years.

If they were not suited for farming because of the altitude, rockiness, stoniness, steepness etc., mountains became in many cases the domain of pastoralism, originally nomadic, later often as part of transhumance. Stock-keeping was mostly combined with tree crops and arable farming, which in many southern regions has been practiced even above $1000 \mathrm{~m}$ a.s.l. Mixed smallholdings with low-intensity farming prevailed. Only locally in the mountains latifundia occurred, like in parts of the Apennines. Locally, monasteries played a major role in mountain exploration from high medieval times on. They had extensive properties, such as those of Vallombrosa, Camaldoli and La Verna in the Tuscan Apennines and of Monte Oliveto Maggiore south of Siena, which also explains the high percentage of forest land in Tuscany (37 $\%)$ compared with the national average (21\%).

For many centuries most mountain villages all over Mediterranean Europe had common lands, mainly pastures and forests. Especially in Spain and Italy, much of it was sold to private persons in the 19th and 20th century. Other parts were transformed in favour of common functions, such as nature conservation, or were forested, as was energetically done in Portugal, Spain, Southern France and Italy from the 1940s on. It disturbed the pre-existing land-use systems radically.

Pastoralism occurred on semi-natural grasslands, heaths, maquis and garrigues, high in the mountains, also above the tree line. Many of these were common lands or open to access. Except for meat, fur, leather and milk, especially wool and cheese were valuable products. 
Many southern mountain pastures were grazed for centuries by sheep and goats that wintered on coastal plains and moved to the mountains during early spring (transhumance). Most Alpine pastures are however grazed by cattle. Some regions, like the French Alps, have both: sheep and goats on dryer and poorer calcareous rock and cattle in wetter climates and on richer soils, e.g. on schist. These cattle consist mostly of special Alpine breeds, such as Grey Alpine, Dappled Red, Rendena, Dappled Black and Chestnut in the Italian Alps (Petretti 1995). They may still play an important role in local economies, like in the Valle d'Aosta where in the Alpeggio land-use system the cattle move seasonally up and down the mountains. Nowadays they are transported in autumn in trucks to industrial farming regions in the Po valley (Brédy 1998; Dupont 1998). Locally still special systems exist, such as with herds of the rare wild Betizu breed in the Atlantic mountains along the Basque coast, and herds of free grazing horses in Galicia that are gathered only once per year.

\section{Portugal and Western Spain}

Its physical geography, its geographical position and history make Portugal a country full of contrasts. This also accounts for adjacent Spain. According to most European definitions of 'Mediterranean', which refer to climate elements and to bioclimatological indicators such as the olive tree, the whole or almost the whole of continental Portugal is Mediterranean. The northern littoral regions of Minho in Portugal and Galicia in Spain might be called Mediterranean-Atlantic, and the highest parts of the mountains Mediterranean-Montane (Figure 1). The Mediterranean and the Atlantic influence mix up in larger parts of Portugal, and the cultural influence of the Mediterranean is strong in the whole country. Portugal and the adjacent parts of Spain can be divided into three large regions (Ribeiro 1991): the South, clearly Mediterranean; the North Interior, dominated by mountains with Mediterranean characteristics; and the North Littoral, with more precipitation and shorter summers than in the rest of the country, due to the Atlantic influence. To the East, the SouthernPortuguese Alentejo gradually passes into the somewhat more continental Spanish region of Extremadura. To the North, Minho passes into the carved coastal zone of Galicia and Trás-os-Montes into the mountainous Galician provinces of Orense and Lugo.

Most cultural landscapes that developed within these large regions are in origin multifunctional. But only some are still managed in the traditional way with multifunctionality at field, farm and landscape levels. West-Iberian landscapes clearly suffer from recent land-use impacts that cause simplifications at field and farm level by rationalization of farming. This does not occur everywhere in the same way and equally strong. Some examples of these complex land-use systems still exist and enable us to unravel their functioning.

From the High Middle Ages on, in the Atlantic mountains of Galicia examples of multifunctionality developed with the intensive self-sufficient polycultures of the minifundismo gallego (Rommel 1994) (Figure 4). Still in 1986 the average farm size was no more than 4.8 ha and the average number of parcels per holding fourteen. The high rents in the 16th century (paid in wheat and wine) and the economic decline of Spain in the 17th century promoted self-sufficiency. Nevertheless a large-scale emigration to cities and overseas occurred as a result of overpopulation, also after a shift to flax cultivation for the linen industry and after the introduction of maize and potatoes, which substantially increased the production.

Similar multifunctional semibocage landscapes with minifundias, developed in adjacent Northwestern Portugal (Unwin 1994). Here, too, the emigration was 
immense. After World War II these landscapes became stressed by an increasing urbanization, but their varied cultivation pattern is nowadays maintained by part-time farmers with garden farming as a complement to the low family incomes. In Northeastern Portugal, with its scattered hamlets, the average farm size is however less small. Many farmers are still full-time farmers. The mosaic of cultures is different from that in adjacent Spain, which has a much drier climate. Actual land-use trends are mainly the rationalization of the structures, the concentration and specialization of production, and the abandonment of the most peripheral parcels.

In the extreme South, the traditional landscapes of the Algarve are known from their small-scale mosaics of permanent tree crops and both dry and irrigated annual cultures. In the coastal zone and in the barrocal, mixed farming traditionally focused on open stands of tree crops with figs, olives, almonds, carobs and pistachio, and underneath winter cereals and pastures. As along many of the South-European coasts, and particularly those of Spain, during past decades the impacts of a combination of recreation, urbanization and agricultural intensification with increasingly more glasshouses and plastic greenhouses has been enormous. On a short distance one may find the chaotic combination of recreation facilities, residences, greenhouses, fruittree groves, harbours, natural sites and small industries. The traditional landscape patterns have irreversibly been replaced by a supermarket of land uses, in arrangements that only incidentally refer to the historical setting.

The recuperation of traditional multifunctional landscapes is hardly realistic in the poorer and dryer areas of interior Algarve, Southern Alentejo, Southern Extremadura and the extreme West of Andalucia either. Here, the traditional silvo-pastoral balance has been broken, and soils have been exhausted by a too intensive dry cultivation since Salazar's 'wheat campaign' between 1929 and 1934. Much of the area is now depopulated, the fields have been invaded by shrubs or have been planted with eucalyptus and recently also with pines. The extensive mono-species plantations of these exotics are not multifunctional at all. They are ecologically poor and socioeconomically not integrated in local farm households. In the way they most often have been laid out, they wiped out the original cultural identities of the landscapes and they moreover became a risk because of wildfires.

Landscapes with intensive, specialized land-use systems with a high economic value may be traditional and specific too. Still, these landscapes of, e.g., the Douro valley with its unique port-wine terraces and those of the rice fields on broad valley flats have at farm and field level largely been transformed by modernization.

Other landscapes kept their identity until now by the survival of traditional farming systems that developed through centuries in using all available natural resources, notwithstanding its abundant natural restrictions. A southern example of landscapes that remained multifunctional at all levels is that of the large-scale montados (Alentejo, Portugal) and dehesas (Extremadura, Spain). A northeastern example is that of the 'hamlet landscapes' in Trás-os-Montes and the mountains of Orense.

\section{Submediterranean France and Italy}

Two closely related traditional multifunctional land-use systems are very characteristic for submediterranean France, some parts of Catalonia, and the foothills and middle mountains of the Apennines: (1) mixed cultures on terraces, in former times frequently with métayage/facherie/perceria/mezzadria tenancy systems (in France, Provence, Catalonia and Italy, respectively), and (2) grazed fruit chestnut forests. Today, there are only few vital examples of them left. 
The Submediterranean coltura promiscua or coltura mista landscapes, i.e. mosaics of mixed cultures on terraces, are prominently depicted on $15^{\text {th }}$ - and $16^{\text {th }}$-century paintings of Tuscany (Vivere nel contado al tempo di Lorenzo 1992), but were already normal in Roman times, as Columella mentioned (Schmitz 1938, p. 89-99). They evolved to landscapes with mixed cultures of tree crops (olives and fruits) and/or vines, with in between either arable crops, vegetables or grassland, on numerous terracettes, constructed with dry stone walls up till ca $700 \mathrm{~m}$ a.s.1.. Similar landscapes occur in Liguria, the Provence, the Cevennes (Ardèche), Catalonia and the Languedoc (Pyrenées orientales, Megret and Collin 1995), and locally elsewhere in Mediterranean Europe too (Figure 4). In the Provence the terracettes are called restanques or oulieres, if smaller. Occasionally irrigation and drainage systems are integrated that may originate from Medieval or even ancient times, such as in the Tuscan Montalbano and Chianti (Baldeschi 2000).

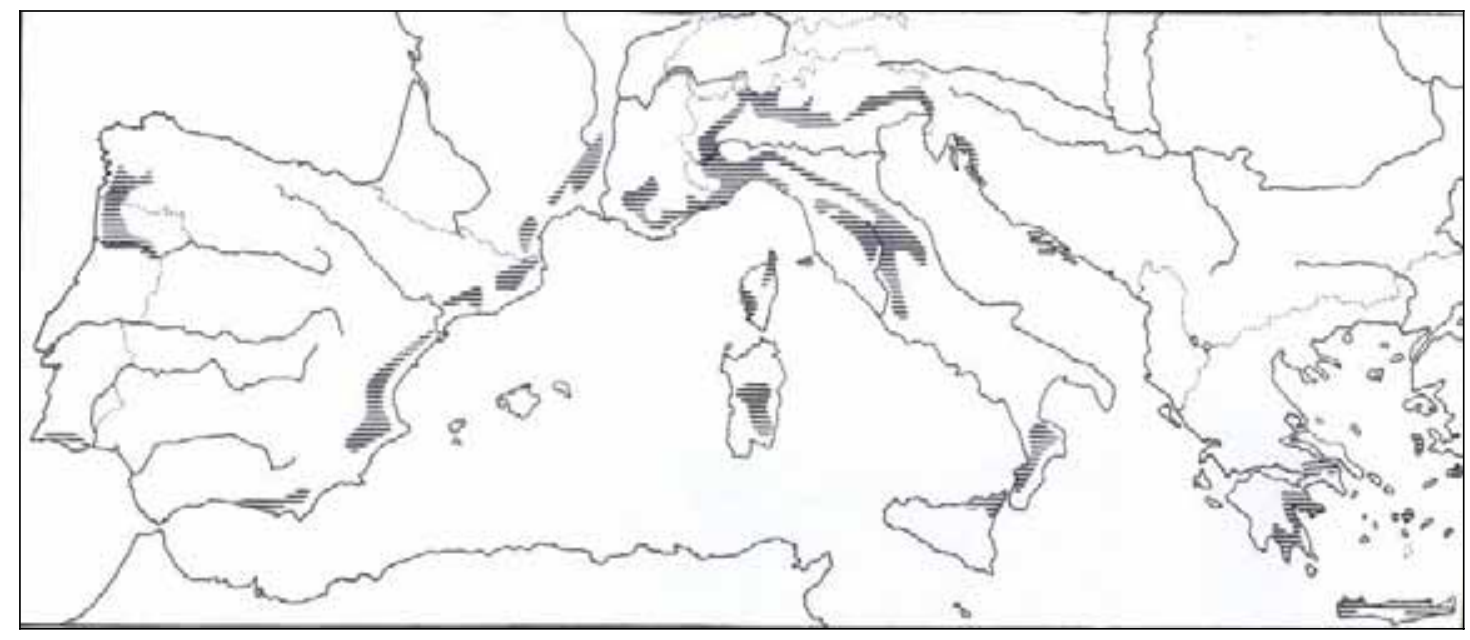

Figure 4. Main landscapes below $1000 \mathrm{~m}$ with old terraces. Originally in many cases with polycultures of tree crops and/or vines, with arable crops, vegetables, pastures; some specialized in commercial monocultures of vines, olives, almonds, etc.

These landscapes always had extensive transportation networks that connected fields, pastures, forests and settlements and enabled the spatial interrelations by the transport of livestock, yields, manure and other production means. Streams delivered irrigation water and gave power to watermills. At different altitudes the nutrient and water cycles were as much closed as possible; e.g. by collecting livestock manure in stables with forest litter, shrub and heath sods and spreading them over the fields; by using the water from streams and wells as efficiently as possible; by controlled postharvest burning; by composting all kinds of detritus; by stubble grazing; by forest grazing and by moving livestock between pastures at different altitudes.

Originally vines were mostly planted on the outer boundary of the terracettes, fruit trees and olive trees everywhere. The vines were mainly stretched between pollarded trees, which could be elms, figs, mulberry trees, poplars and ash trees. According to Plinius the Elder (A.D. 70), who also mentions brickwork, trellis, props and selfsupporting constructions (ad alberello), this occurred already in Roman times (e.g. Toutain 1968; Sereni 1997). As elsewhere in Europe, the leaves of elms and other tree species were used as fodder for cattle, and the branches as binder for the vines.

In the 15th and 16th century olive trees became increasingly important in coltura promiscua systems and even replaced vines in some regions, especially on less 
suitable soils. In the same period the number of almond trees and walnut trees in polycultures increased. Sometimes tree crops were mixed, such as olives with figs. Under the tree crops and vines wheat, oats and vegetables (lentils, peas) were cultivated and later locally in the Provence also e.g. lavender and flowers. Rotations (two- or three-course) were normal, such as of alfalfa and wheat (every fourth year), and also post-harvest stubble-grazing by sheep and goats, combined with mulching and controlled burning.

Apart from the tree crops of the coltura promiscua, also grazed fruit-chestnut stands were integrated in the submediterranean mixed farming. These multifunctional stands belong to the broad category of indigenous tree crops with varying densities (chestnuts, olives, carob trees, almond trees, hazel trees, cork oaks) that are important components of many traditional Mediterranean landscapes. They vary from strict orchards to savannah-like grazed, open stands. Their management evolved over millennia and proved to be very sustainable as it is well adapted to local conditions, which implies that mostly no irrigation, fertilization and pesticides are needed. In fact, they are like substitute nature, a semi-natural open forest (Vos and Stortelder 1992). Apart from their yields, tree crops are favourable as they stabilize terracettes, capture precipitation and may shelter livestock and more vulnerable fruits trees such as figs, apricots and pomegranates.

Chestnut forests had a major role in the farm household of many submediterranean landscapes on non-calcareous, deep soils, especially in France (e.g. Cevennes, Roussillon-Languedoc, Corsica), Italy (Liguria, Emilia-Romagna, Tuscany, Umbria), Spain (Catalonia, Galicia, Asturias, Andalucia) (Figure 5), Portugal (Trás-os-Montes) and Greece (Thessalia, Peloponnese, Crete). They delivered shelter and fodder for sheep and pigs, leaf mould, firewood, fences, chestnuts as food for people and pigs, timber, mushrooms, manna (a kind of honey), wildboar meat and hides. They were also important for the stabilization of slopes, the regulation of water run-off, water quality and climate, and the amenity and identity of a region (Vos and Stortelder 1992).

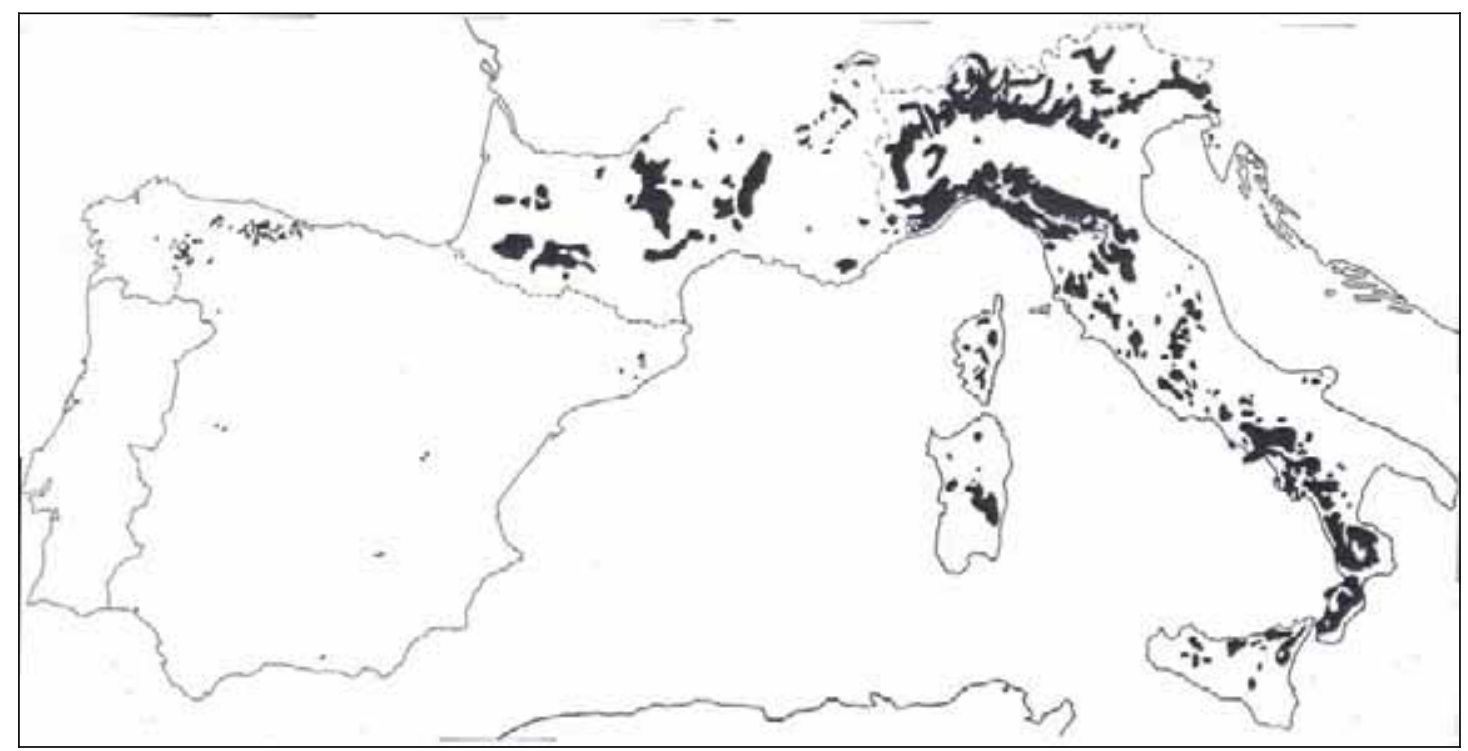

Figure 5. Selva castanile landscapes in Northern Spain, France and Italy before WWII (data: Commission du Châtaignier 1951; Fenaroli 1958; Gran atlas de España 1989) 
Locally other crops took the niche of chestnuts, such as white mulberries in the Cevennes (Ardèche), which made the Cevennes for a long time the most important French centre of silk production. The maximum extension of the bread tree (chestnut) and the gold tree (mulberry) was reached between 1760 and 1820 and so was the maximum population (Megret and Collin 1995). Other mulberry centres were for instance located in the Provence and other parts of Southern France, in the North of the Po plain, parts of the Spanish Levante, Thessalia in Greece and on Crete. The disease of the silkworm from 1845 onwards and the competition with synthetic materials and oriental silk after 1880 caused the decline of mulberry trees in the Cevennes landscape and in other regions.

Other regions specialized on other tree crops, such as carob trees for fodder (e.g. Algarve), walnuts (Emilia, Campania), almonds (Algarve, Levante), avocados, passion fruits, loquats, apricots, nectarines, pomegranates. But none of these were so multifunctional and so much integrated in the farm households as canopy chestnut stands.

\section{Multifunctionality in disgrace}

\section{Mediterranean mountain landscapes}

The hard and unreliable conditions of Mediterranean mountains and their distant location made them not very suitable for monofunctional specialization. Pastoralism, forestry and mixed farming developed complementary strategies in dealing with these conditions. Only after World War II recreation, tourism, nature management and other activities achieved a growing significance in local economies.

A very outspoken way to deal with both summer droughts in the lowlands and winter cold and snow in the mountains, is the transhumance, which once occurred all around the Mediterranean (Figure 6): a nomad-like system with seasonal migration of large herds of sheep and goats (in former times together up to many millions) between lowlands and mountains. The animals moved along more or less fixed droves that became main landscape elements for centuries. In Castilia they were called cañadas, smaller roads cordeles or veredas, in the Eastern Pyrenees camis ramaders, in the Languedoc drayes or drailles, in the Provence carraïres, in Italy tratturi or tratturelli, on Sicily trazzere, in Romania drumul oilor, in the Pindus vlachóstrata. More smallscale livestock movements also occurred, like the so-called trasterminancia in Spain. The system probably originates from nomadism (Braudel 1966) and existed from antique times on. In many regions it vanished, and where it survived, the animals are nowadays most often transported in trucks (in former decades by train). Houston (1964) and Braudel (1966) mention three possible forms:

- The normal transhumance with shepherds from lowland farms that move in the summer to mountain pastures that frequently were their property. An example is the seasonal movement from the Camargue (Arles) along the Durance uphill towards the pastures of the Oisans, the Dévoluy, the Vercors, the Maurienne and the Tarentaise.

- The inverse transhumance with shepherds from the mountains who move to lowlands in winter and seem to 'occupy' them, which frequently causes tensions with the settled farmers, who have herds too (e.g. McNeill 1992). Examples are the movements from Roman times on between the Abruzzi and the Apulian Tavoliere, with during the Renaissance three million sheep (Houston 1964), between the Abruzzi (Gran Sasso, L'Aquila) and the coast near Rome until the first half of the 20th century (Desplanques 1971), in Greece from the Pindus and the Peloponnese 
mountains towards coastal plains, from Graubünden towards the plains near Venice that continued for centuries, from Pyrenees villages like Prades and Montaillou to the winter pastures of Catalonia (Le Roy Ladurie 1975), and from the 16th century on from the Bask Pyrenees towards the lowlands of Navarra onto the Bárdenas Reales. The most prominent and best described transhumance was organized by the Real Concejo de la Mesta, whose rights date from 1273. Their herds moved from León, Segovia, Soria and Cuenca over fixed droves through Castilia to the Guadiana basin. In the 15th century Alphonse I of Aragon introduced a similar kind of organization in central and Southern Italy (Dogana della Mena delle Pecore for the Agro Romana in 1402 and the Dogana di Puglia for the Tavoliere in 1443).

- A mixed form of transhumance, where the shepherds lived half-way between the mountains and the lowlands, as in the Chataigneraie on Corsica and between the Crau and the Maritime Alps.

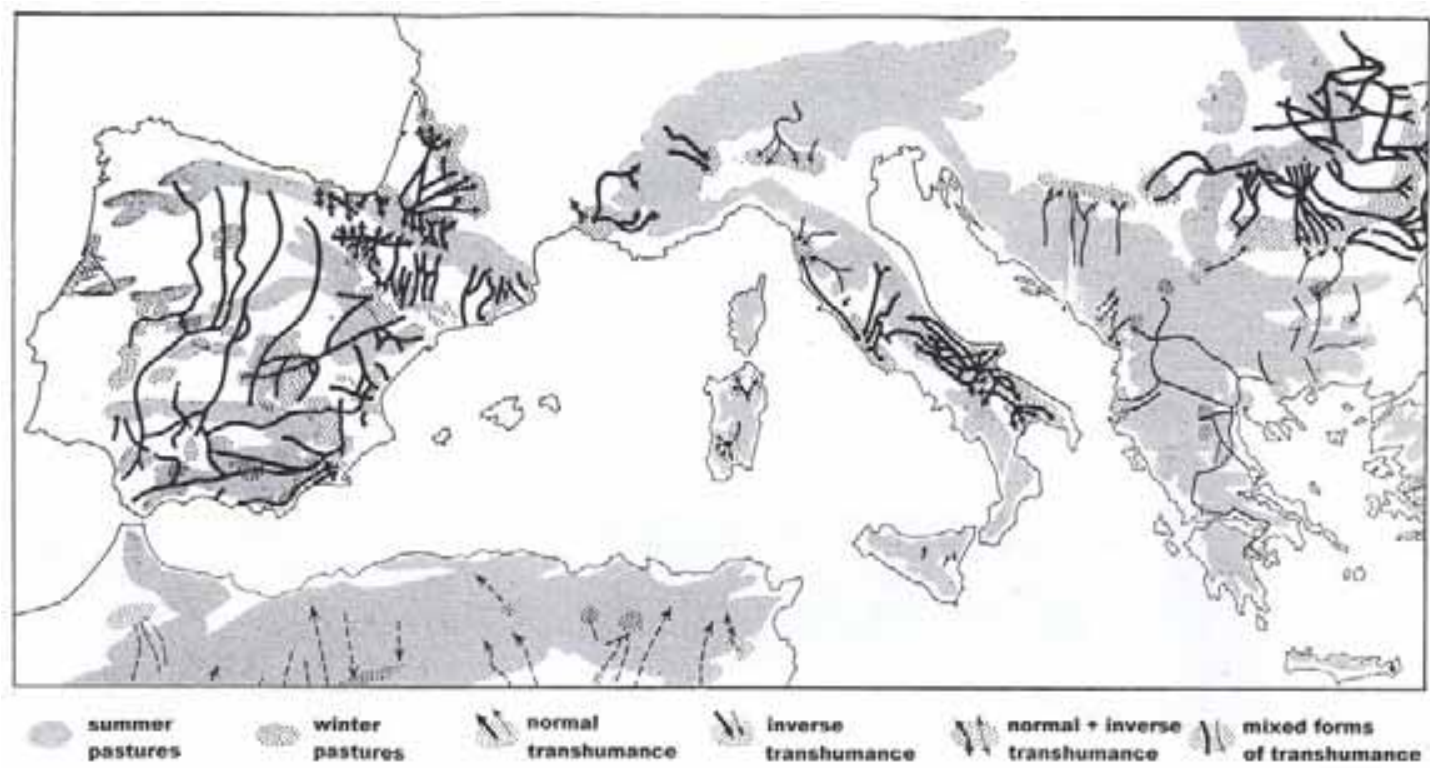

Figure 6. Transhumance routes, mapped before WWII (after F. Braudel 1966, with reference to E. Müller 1938. Die Herdenwanderungen im Mittelmeergebiet. In: Petermanns Geographische Mitteilungen)

In general only a part of the mountain population was engaged in the transhumance as complementary to peasantry, forestry, charcoal burning etc. Sometimes the shepherds also had some arable fields. The stockbreeding with transhumance was altogether rather multifunctional (Figure 7). The sheep contributed to the fertilization of fields from stables and by stubble grazing. It frequently occurred that land that was passed by sheep was leased to farmers because of the enrichment by the manure. The transhumance was moreover an important factor in the ecosystems. Open landscapes were maintained together with many outstanding plant species and allied animal species. Many insect species were closely connected with the sheep and goats themselves and their droppings, which attracted predating birds and mammals, together with larger predators such as vultures, raptors, wolves etc. The latter also lived from the dead, sick and young domestic animals. 


\section{Transhumance}

amenity, biodiversity, historical information, abiotic regulation

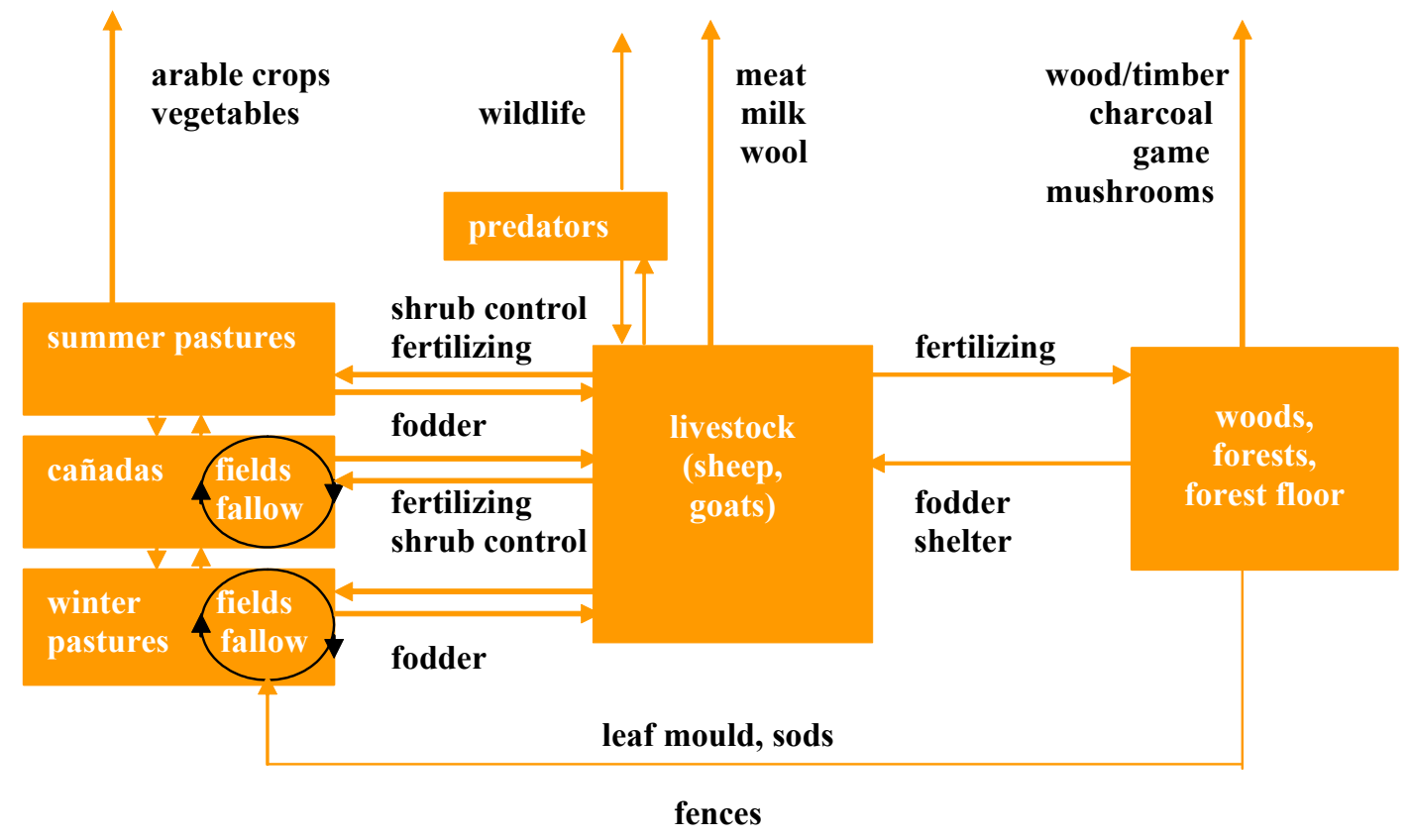

Figure 7. Scheme of the transhumance land-use system

Basic causes of many changes in mountain landscapes are that it is too difficult to make a living and that life looks more attractive in urban centres. Also the use of compound feed and dry forage, more intensive management (daily milking, direct selling of milk and cheese-making), subsidies for transport, and the greater convenience for sedentary farms in claiming subsidies contributed to the decline of mountain pastoralism and transhumance (e.g. Beaufoy, Baldock and Clark 1994). In regions like lowland Attica, the Provence and the Tuscan and Lazian Maremma it became nearly impossible to rent lowland winter pastures, due to an increasing competition for land. Also forestry and arable farming in the mountains were not profitable anymore, and as the multifunctional integration of silva, ager and saltus at the farm level was the economic backbone of society, many mountain regions were abandoned.

Large-scale emigration started in some regions already in the second half of the 19th century and sometimes continues until today: pastures, fields, woodlands and long-distance droves were abandoned and subsequently nature took over. Buildings, walls, terraces and paths decayed. The number of farms in the mountains in general declined more than the area under cultivation. Transhumance still exists only locally, with much less livestock and with in most regions trucks as the main means of transport. In the best case, pastoralism, forest use and arable farming are maintained at a simple level without coherence and with the help of subsidies and a complementary income from recreation (mountaineering, skiing, long-distance walking).

In order to stop the vanishing of traditional mountain landscapes, several policy measures have been developed during the past decades. But most of them support 
only specific elements or focus on the replacement of old elements by new ones: antierosion forests with exotic conifers on rough pastures and abandoned fields, transformation of coppiced and pollarded stands into high forests, new recreation facilities, improved roads and subsidized mechanical transportation.

Some autonomous developments with apparently economic perspectives also occur and in part replace the traditional land use. Examples are the development of various forms of intensive bio-industry, with pig, chicken and dairy breeding in large stables (e.g. in Galicia), outdoor recreation and tourism, with ski resorts, campgrounds, long-distance walking paths and the restoration of farms as second houses for urban people. So-called agritourism is of growing importance in distant Mediterranean mountains, although still at a low level.

In the past century many nature parks and reserves have been established in the mountains of all Mediterranean countries. At the start, their objectives were restricted to the conservation of fauna and flora and their habitats, which in practice meant a focus on a limited number of flagship species, such as brown bear, wolf, Iberian lynx and Alpine ibex. More recently in many parks the objectives have been broadened towards sustainable low-input economies, as these are main conditions for sustainable agro-ecosystems. And thus towards the continuation of traditional land use and the related open rural landscapes, such as with cattle breeding on alpeggi (high-altitude summer pastures grazed by local dairy breeds) in the Parco Nazionale del Gran Paradiso (Poole et al. 1998), sheep grazing on wood pastures in the Vercors Regional Park (Osterman 1994), sheep grazing on Nardus grasslands in the Mercantour National Park (Lambertin 1998). In many cases this was done with incentives to farmers/shepherds from EC agri-environmental measures of Regulation 2078/92, and more recently also from EU Structural funds for Less Favoured Areas and for Regional Development. Measures comprise subsidies for facilities, for adapted management practices in favour of biodiversity and for keeping local breeds. They focus on a broad spectrum of objectives in zonal programmes (Povellato 1997; 1998).

However, in some mountain regions, such as the Abruzzi, for a long time EU measures were not applied because of ignorance and incapacity of farmers and the regional government, unclear ownerships of the land and laborious procedures (De Sanctis 1997). And if the measures are applied, in many cases they only help to keep the old façades, but not the integral landscapes. Moreover, other subsidies, such as from the EC Afforestation Regulation 2080/92, may work in an opposite direction by promoting transformation from low-intensity farming and pastoralism into production-oriented forestry. These developments prevail today in large parts of the Mediterranean mountains. Still, locally also a new multifunctionality, based on the selling of the added value of agricultural products from traditional farming together with nature conservation and tourism, offers new perspectives. Part-time farming also becomes increasingly important.

\section{Small-scale hamlet landscapes in Northeastern Portugal}

The mountainous Northeastern region of Portugal has an irregular topography, with long and steep slopes, deep valleys, some plateaus and some valley flats. On the latter an intensive arable farming has developed. But elsewhere complex systems of mixed land uses prevail, with small properties and small plots, very often on terraces, arranged around central villages. These constitute so-called hamlet landscapes (Grove and Rackham 2001). There are some variations in these agro-pastoral systems, depending on slope, altitude, orientation, soil types, geographical location etc. (Lima e Santos 1996), but their complex structures are similar (Ribeiro 1991). 
In addition to the commons at higher altitudes, each farmer uses his own small property, divided into different plots dispersed over the area, normally with different land-use types. Nutrient cycles are as much closed as possible by applying stable manure of cattle, mixed with shrub, on the fields, by using chestnut litter and forest soil for improvement of the land, by post-harvest stubble grazing of sheep and goats that at the same time drop their manure on the land, and by keeping the precipitation and run-off with its load as long as possible within the farming system, e.g. by irrigating meadows. The fields are located on small terraces with dry stone walls. Around the villages vegetable gardens, fruit orchards and plots with arable crops such as cereals and potatoes are located.

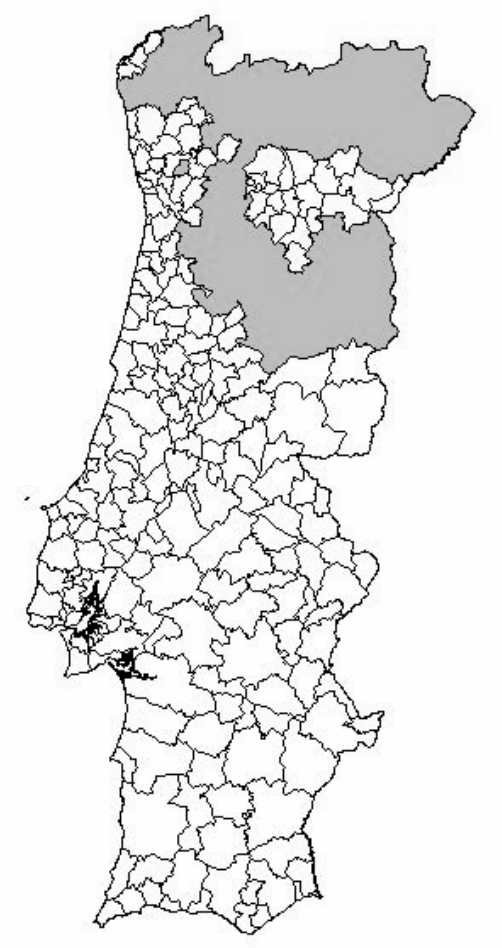

Figure 8. Area in Northern Portugal where lameiros may occur on the valley flats

On valley flats where water is available, a complex system of irrigated meadows (lameiros) occurs (Figure 8). They are inundated through a network of small channels, commonly managed by the village, with many local variations (Portela 1996). The irrigation promotes the productivity of grass for grazing in winter and spring, hay in the beginning of summer, and grazing later again, mainly by beef cattle. The use of the grass throughout the year demands a careful grazing regime. Rows of trees are planted between fields, on other open plots and along the canals and streams. Trees along the lameiros are pollarded or coppiced and the leaves are used as a complement in livestock feeding. The branches are used as fences or fuel wood. In areas with chestnut trees, the chestnuts are yielded as human food and animal fodder. By bringing the cattle to stables every evening, their manure may be used as a fertilizer for the fields. Sheep and goats usually graze on the commons and keep the shrubs under control. These rough pastures are a mixture of stone outcrops and shrubs with a varied composition. As the resources are scarce and the climate is very variable, not only all possible resources were used in former times, but each farm also invested in different products at the same time. Risks were diminished in such a complex mixed 
system with fluxes in various directions (Figure 9) (Pires and Moreira 1995; Taborda 1987).

\section{Lameiros}

amenity, biodiversity, historical information, abiotic regulation

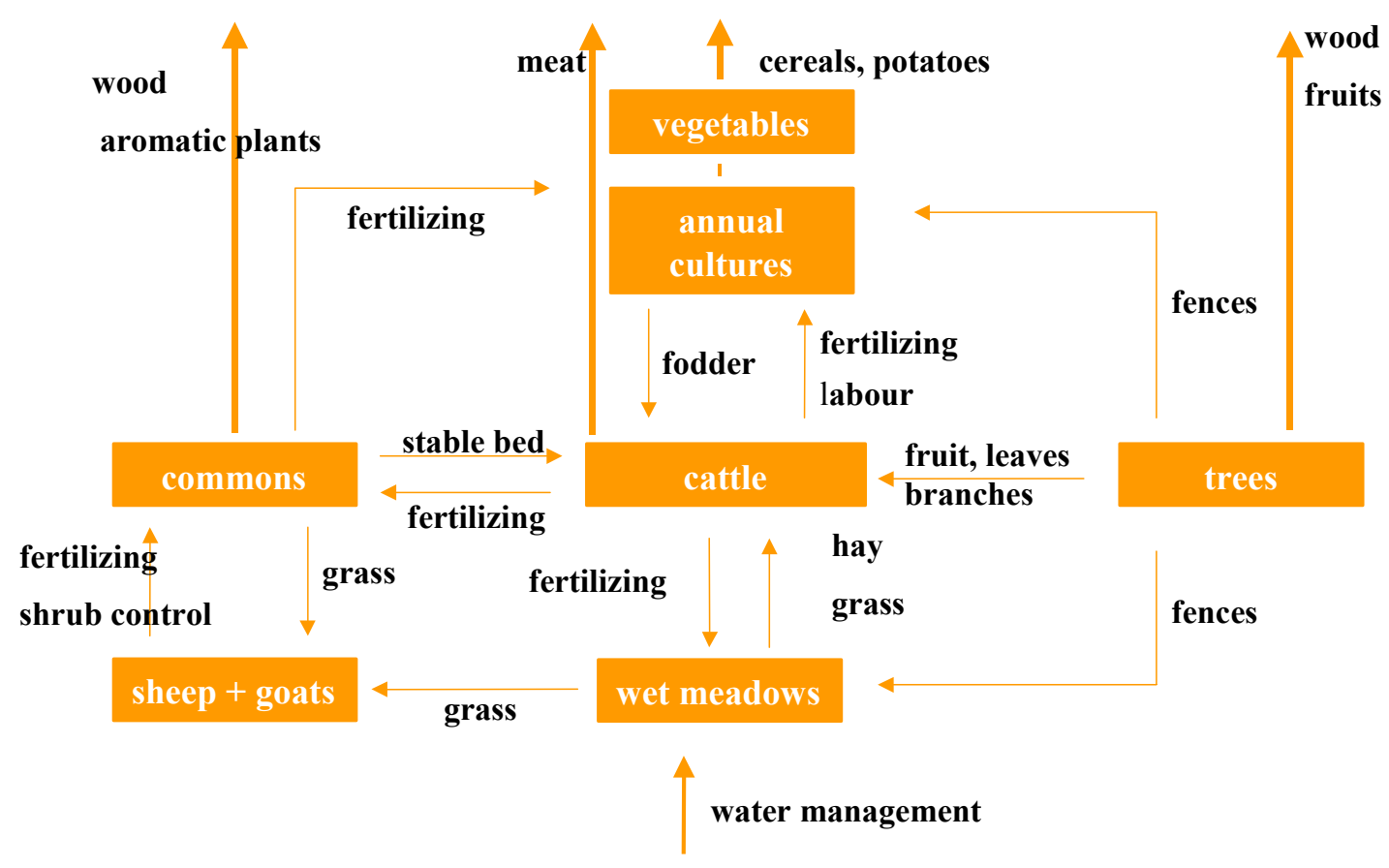

Figure 9. Scheme of the lameiros land-use system

This small-scale hamlet system was most complex and most widespread in the first half of the 20th century, when population densities peaked and farming was the only source of income. In the 1940s and '50s extensive commons were however appropriated by the state and planted with mono-species production stands, and thus withdrawn from farming. This strongly reduced the livestock production potential of many villages. At that time many farmers emigrated, which diminished the population pressure. Nevertheless, the traditional farming system has locally been maintained until today. In some places more completely than in others, but at least a part of the small-scale landscapes was kept.

In these landscapes multifunctionality was high at various levels. At field level, the production was interrelated with biodiversity support, water management and the preservation of historical patrimony with traditional techniques and artefacts. For the biodiversity especially the lameiros were important, with a multitude of often vulnerable and sometimes rare species. Also at farm level a diversified production was combined with the management of water, slopes and terraces. At landscape level all functions sustained the regional identities (natural, cultural, aesthetic) and offered a potential for recreation and related activities.

Although some land-use systems and traditional landscape patterns remained almost intact, local case studies and interviews with regional experts and actors have shown that some major changes take place (Rodrigues 1996; Lima e Santos 1996). A prevailing trend is, without any doubt, the simplification of the land-use systems. 
A case study in six representative villages, carried out in 2001 and 2002, shows that different strategies are used for the continuation of farming. In some areas, where livestock breeding is too difficult, there is a shift towards arable crops (rye) or tree crops (olive, chestnut), both highly subsidized by EU measures. This happens for instance in villages where the younger generation of land owners left, but still returns in weekends and holidays and then is engaged in part-time farming. In some villages one or two dynamic young farmers stayed and focused on crop production on own land and on leased land, besides doing machine work for others. Around these villages, the wet meadows are disappearing, the common land is covered by a dense, high shrub, and the marginal plots are abandoned or eventually planted with subsidized chestnuts or olive trees. Since the population is limited and may buy their food in distant shops, the area of vegetable gardens and fruit orchards gets smaller every year. So, both labour-extensive and labour-intensive units are abandoned.

In other villages, where crop cultivation is more difficult as plots are smaller and the soil is less productive, also chestnuts and olives are not suited. Here, the focus is on cattle breeding. This may be profitable if there is a regionally specific cattle breed, and if there are subsidies under the EU Agri-environmental Programme for its production. In these cases, sheep and goat breeding is disappearing. For the farmers who stay, it is easier to focus on cattle, also as more meadowland becomes available and the lameiros and their irrigation systems are supported by EU agri-environmental measures. But whereas the meadows are maintained, the cultivated area decreases, and the commons are abandoned, with risks of fire. Nowadays some farmers are engaged in traditional coppicing and pollarding along the meadows, mainly motivated by their aesthetic values and the wish to keep up tradition.

In villages with less lameiros, and at the same time with a vital communitarian tradition, stock-raising focuses on sheep and goats. Wet meadows are abandoned, since they demand a permanent care. When also the cultivated plots are abandoned, the irrigation structures and the terraces collapse and shrubs invade rapidly.

With both strategies (either focusing on cattle or on sheep/goats) the mosaic of vegetable gardens and orchards is reduced. Some components of the traditional land use are maintained by remaining older people. Other components may be kept by younger farmers, although in a rationalized form and often not integrated with each other. The small-scale hamlet landscapes are still there and there are still variations within the region, but the simplification of land use and landscapes is progressing, with as a result a reduced multifunctionality at all levels.

\section{Tuscan former coltura promiscua landscapes}

When people refer to the famous landscape of Tuscany, they most often think of landscapes somewhere in the triangle Florence - Pisa - Siena, such as the submediterranean hills and middle mountains of the Chianti and the Montalbano, west of Florence. Located in the vicinity of Fiesole and Roman Florentia, they display an old history, which is shown by Etruscan, Roman and Medieval artefacts and impacts of former land use. They belong to the most characteristic former mezzadria landscapes, with originally a sharecropping system that obliged the tenant to pay to the landowner half of the yield or more in products. Characteristic was also the traditional coltura promiscua with olive groves, vineyards, locally fruit orchards and mixtures of these on terracettes (Baldeschi 2000; in preparation), and moreover a full use of all possible resources. Its outcome was as multifunctional as can be: from commercial crops (grapes, olives, fruits) and subsistence food (cereals, vegetables, meat) till amenity, water and erosion control, preservation of natural and cultural 
heritage (Figure 10). Main elements that have survived until today are complexes of numerous terraces with dry stone walls and old irrigation and drainage structures. The man-made constructions are in fact continuously rejuvenated as they are subject to weathering and erosion as well as to the benefits of new technologies (Baldeschi 2000). With a growing population, especially in the period from the 18th till begin 20th century, the area with dry stone walls and terracettes increased considerably.

\section{Coltura promiscua}

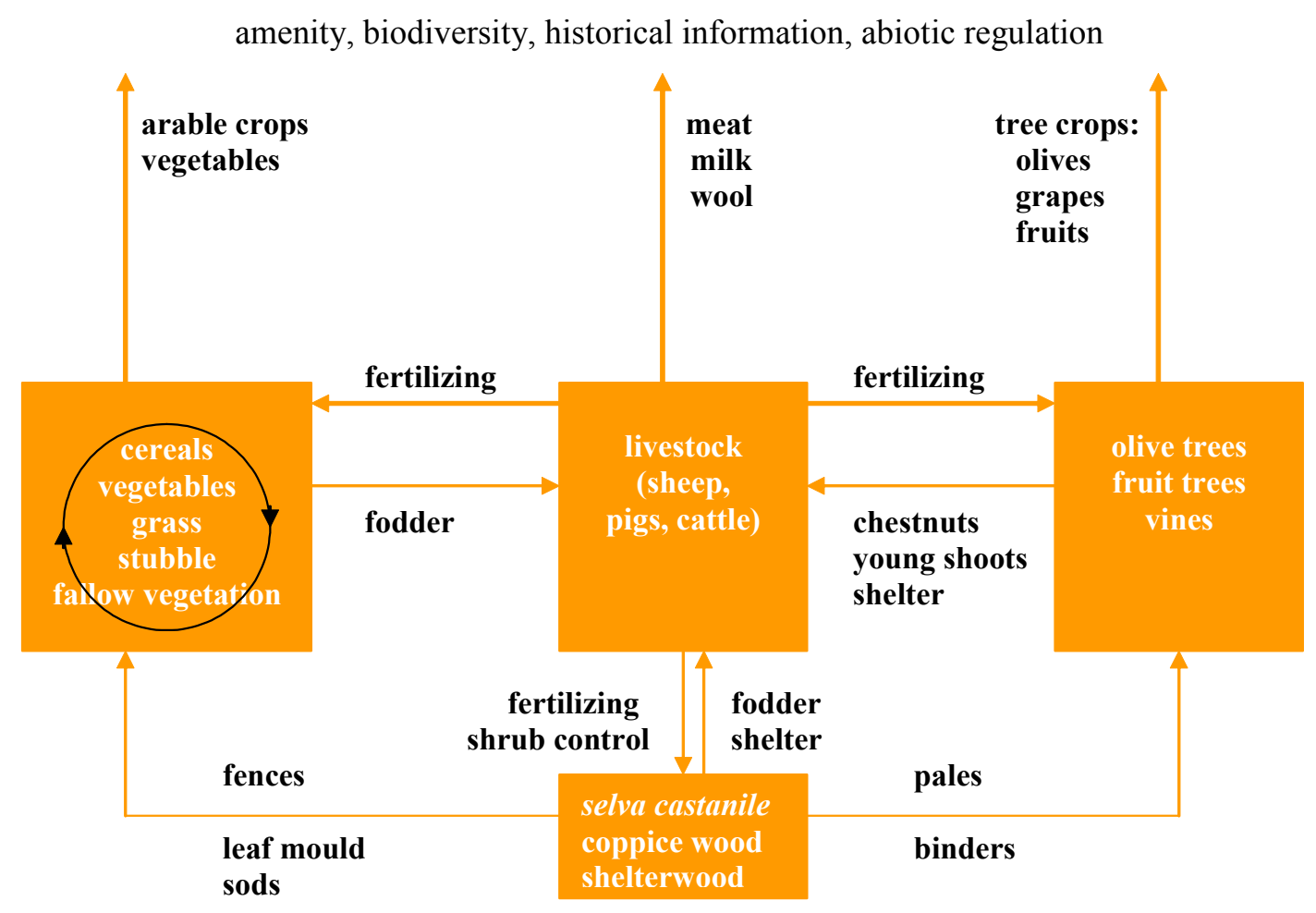

Figure 10. Scheme of the coltura promiscua land-use system

At a first look, with their terraces and small hamlets, they seem to have much in common with for instance the landscapes of the Trás-os-Montes. But here, we do not deal with a distant area and a poor backward society that had to manage as soberly as possible. Here, we are in the heart of Etruria, for more than 2,500 years one of Europe's main cultural centres. What began at least with the Etruscans and culminated in the Renaissance with the De' Medici's, is still vital today. In the countryside of the Chianti and the Montalbano small farmers made a living on their own land, while predominantly living in villages and towns. Where the urban influence was greater, more sharecroppers occurred that lived in farms on the land of rich urban people. The latter could afford to invest in the countryside, with castles, fortified towns, villas and fattorias on only a couple of hours riding from Florence, Pistoia and Prato. Here, in the hills with a comfortable climate many large villas with estate gardens are located, such as those of the De' Medici's nearby the Barco Reale Mediceo (established in 1626) on the Montalbano: Villa La Ferdinanda, Poggio a Caiano, La Magia di Quarrata, Lambrogiana, Cerreto Guidi and Montevettolini. A major function of the Barco Reale forest under the De' Medici's was hunting, but a large part of the forests from about $300 \mathrm{~m}$ above sea level up to the divide consists of canopy chestnut stands 
that were grazed by pigs and sheep and were integrated in local farm households in the 18th till beginning of the 20th century.

Also these landscapes were multifunctional at field, farm and landscape level, and although they are not located in a poor distant region, they were also subject to major changes during past decades. This was reinforced by the laws that ended the sharecropping in the sixties and promoted a shift from traditional economic behaviour towards modern business attitudes. The consequence was a loss of non-monetary values and land-use practices, which include the replacement of manpower by technology (machines, biocides, chemical fertilizers). As in many other landscapes, two types of processes were active: (1) abandonment and extensification of the least suited sites, and (2) intensification, upscaling and transformation in favour of industrial techniques and facilities (Vos and Stortelder 1992). The latter occurred especially where valuable DOC grapes do well, such as in the Chianti. One of the results is that nowadays only very locally mixed cropping under olive trees occurs, upslope the Montalbano. Here, mostly only the groves are left on decaying terracettes, to be harvested in high-production years and then only at lowest costs: by the farmer himself. Only hollow façades remained of what once was an integrated multifunctional production system. Land abandonment is limited to these altitudes and occurs especially close to the forest. Pastures are totally disappearing, as under the present conditions pastoralism is not profitable anymore. In the Chianti most vineyards with mixed cropping have become specialized monocultures, which started already centuries ago. Also in the Montalbano modern monofunctional vineyards, cereal fields and to a lesser extent specialized olive groves are progressing at the costs of traditional multifunctional low-intensity olive groves with mixed cropping. Investments in vineyards for top wines pay themselves back easily; intensive olive groves are promoted by EU subsidies. The latter have the limitation that subsidy is for the weight of olives instead of for the maintenance of the whole system.

Locally farmers are still engaged in the management of small mesophilous woods, mostly coppice and in part also of chestnut stands. Related to the changing land use is the decay of dry stone walls, especially on steep slopes, and the loss of traditional styles in modern constructions. Together with the walls, the hydraulic systems with old aqueducts degrade. Results are increasing soil erosion and decreasing waterretaining capacity of the soil, which contributes to greater risks of flooding (Baldeschi in preparation). In the same time, the near-by cities cause a strong urban pressure. People who work in town occupy many farmhouses, and their farmyards have become gardens.

It is however a growing public and private concern to create a sustainable future for the multiple functions of the Tuscan landscape. An example of a counteractive movement is that of small landowners with less intensive crops who organized themselves in co-operatives such as that of 'Terre del Gallo Nero' in the Chianti area (Petretti 1996). It aims at reducing management and milling costs, and at enhancing sales by using local trademarks of high-quality oil with a very high added value through the specific regional character. Additional incomes come from agri-tourism, which also may increase awareness for the qualities of the more traditional landscapes.

Except for the local farmers' initiatives and the engagement of urban people with the historical identity of these landscapes, no specific measures exist for the integrated conservation of these traditional production landscapes. 


\section{Fruit chestnut landscapes}

Multifunctional chestnut stands are widespread in the submediterranean mountains and hills with acid soils (Figure 5). In many regions they were for centuries the backbone of the local rural household. They are not so much a commercial good, as the market for their fruits (fresh, roasted, flour) and wood is limited, but they deliver a broad array of products and functions for the farmers themselves (Figure 11). They function as silva, saltus and ager in one, with all replaceable and nonreplaceable products of a forest, together with sheltered pastures, and chestnuts that may replace the flour of cereals and are moreover fodder for pigs. Locally, still the specific attributes of this traditional culture may be found: buildings for drying and roasting, watermills with canals and sluices for making flour and an infrastructure to give access to the groves. Until recently, many farmers in the Apennines owned or leased a chestnut stand as part of their enterprise (Vos and Stortelder 1992). Whereas small stands occur in many places with deep acid soils, extensive chestnut landscapes with kilometres of canopy forest (selva castanile (I), castinçal (P), castanyar, castanyerar (Catalonia), châtaigneraie (F)) occur especially within some submediterranean regions, where they had been integrated in the farm households at least since the Middle Ages. Extensive chestnut forests occur for instance between ca 500 and $1000 \mathrm{~m}$ above sea level in the intermontane basins of the central Apennines: Mugello, Val d'Arno, Val Tiberina, Casentino (Vos and Stortelder 1992; Agnoletti 2002). The chestnut trees behave quite naturally in reproducing, but are still a crop, although with long cycles up to 200 years and with maximum fruit production approximately at an age of 100 years. The open chestnut stands strongly contribute to biodiversity with specific habitats for plants of light, semi-natural forests (Vos and Stortelder 1992) and extensive wildlife habitats.

\section{Selva castanile}

amenity, biodiversity, historical information, abiotic regulation

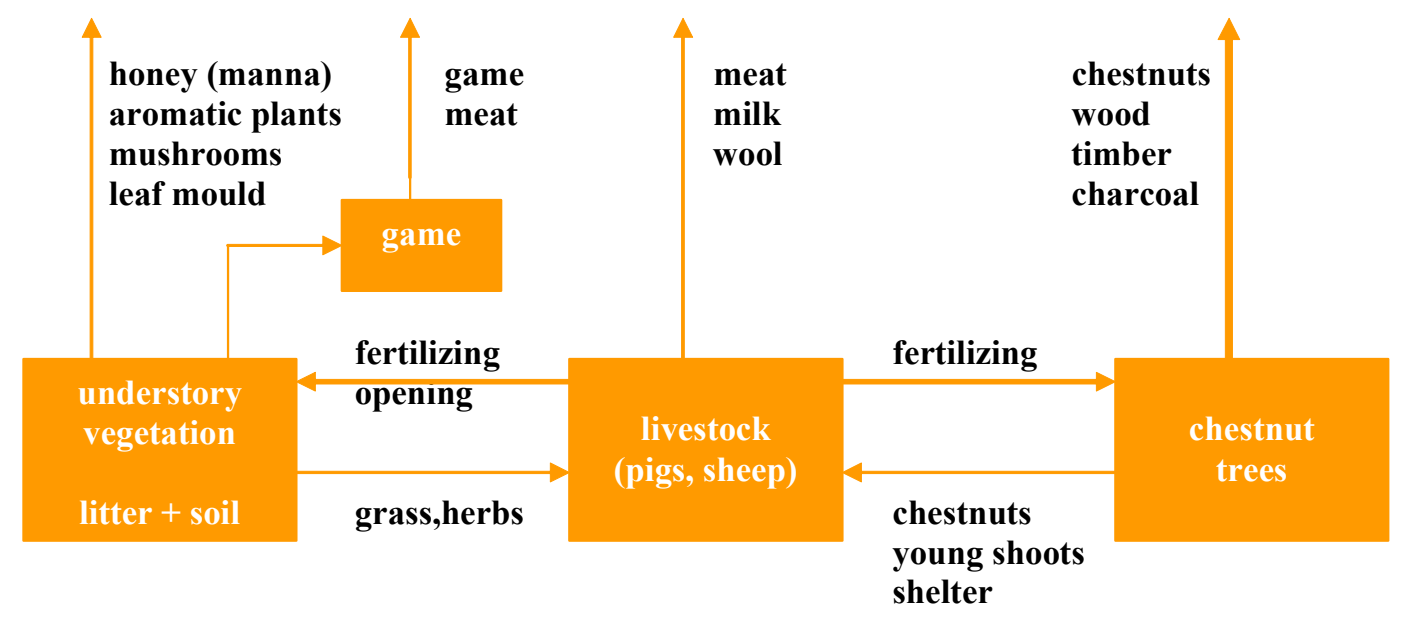

Figure 11. Scheme of the selva castanile land-use system

The raison d'etre of fruit chestnut forests in these landscapes was the multiple role they played in feeding the farmers and their pigs and in producing fuel wood, poles, and shelter etc. Without farmers with their herds, pruning and thinning, these forests cannot survive like in former days, which became for instance clear with the past 
exodus from the Apennine mountain villages. As a consequence of the abandonment of the open stands, shrubs invaded, followed by oaks and other species typical for the natural vegetation, gradually transforming it into a semi-natural forest. At the same time trees were attacked by diseases (chestnut blight and chestnut fever) that killed numerous centuries-old canopy trees. Locally, like in the Monte di Portofino Reserve in Liguria, wildlife species such as wild boar and viper expanded to such numbers in the abandoned forests and adjacent fields that they are considered a plague. In order to make the abandoned forests profitable yet, many trees were cut and stands were transformed into monofunctional coppice with cycles of 8-12 years, to be harvested as poles (the so-called paline). A more rigorous way of dealing with them is cutting and replacing them by conifers (e.g. Pinus nigra).

In some exceptional cases, such as in Northeastern Portugal, another trend can be observed: as a direct effect of high EU afforestation subsidies the area of chestnut groves is increasing. The plantations of chestnut trees in industrial stands is convenient for those landowners who left the countryside to make a living in urban centres, but want to make money in a simple way with long-term investments. EU subsidies contribute to the costs of planting and management, and the chestnuts are expected to give an income in the future: at least in this moment in Portugal the fruits are sold for good prices. The newly planted plots are fenced to keep out livestock, which disturbs pre-existing livestock paths for those who still have livestock. The previous integration of chestnut stands with grazing and other land uses has vanished.

Altogether, the traditional multifunctional selva castanile is rapidly disappearing from many traditional Southern European landscapes, together with the characteristic buildings and infrastructures related to them. There is so far no adequate strategy to keep them, or to define alternative systems and patterns, except for a museum-like setting.

\section{Large-scale extensive landscapes in Alentejo and Extremadura}

The extensive region of Alentejo, in Southern Portugal, is totally different from the northern part of the country. It is characterized by gentle slopes and poor soils, covered with extensive savannas, a Mediterranean-Continental climate with strong annual fluctuations and very large farm units. The dominant land use is that of the agro-silvo-pastoral - actually mainly silvo-pastoral - system called montado, similar to the Spanish dehesa (Figure 12). Both adapted to local environmental capabilities and restrictions. It was mainly optimized in the 19th and the first half of the 20th centuries (Pinto-Correia 1993). Nutrient cycles are controlled by pigs that feed on acorns, shrubs and grasses under the trees, and eventually also by other livestock. The animals drop their manure under the trees and loosen the soil. Careful tree management and controlled grazing promote the infiltration of precipitation in the soil. The large farm units have been owned and maintained for centuries by rich families or societies. Permanent and temporary farm workers, mostly without land, do the work. 


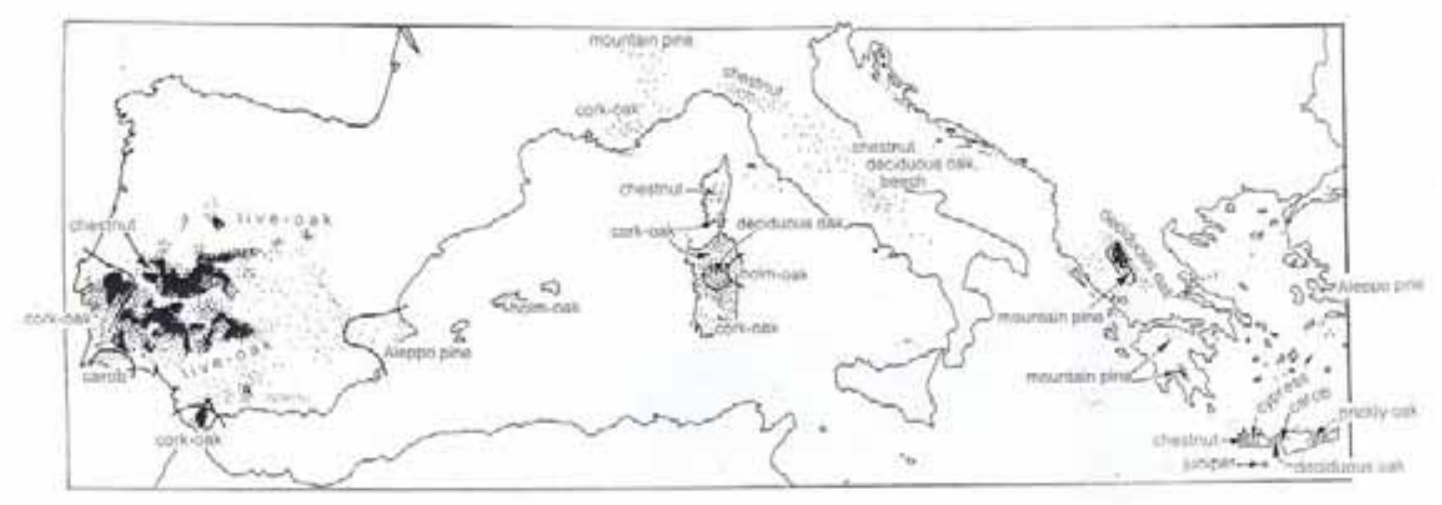

Figure 12. Mediterranean savannas, including montados and dehesas, with their principal tree species (Grove and Rackham 2001)

The montado is a complex system with various components and multiple outputs (Figure 13). It needs to be kept in balance through a sensitive and integrated management in order to integrate all its components in a long-term sustainable way (Joffre, Hubert and Meuret 1991; Pinto-Correia 1993). Trees are cork oaks, holm oaks or both. Cork oaks demand more humidity and are mainly located closer to the coast or at higher altitudes; holm oaks grow under more extreme conditions of temperature and drought, and are widespread. The tree cover has a varied density, between a few and 80 or 100 trees per ha, depending on soil conditions, water supply and objectives of the farm production. The traditional field rotation is cereals-fallow-grazing. The livestock can be cattle (the Alentejo small and light breed), sheep, goats or Iberian black pigs. The livestock remains outside all year, eating grass and acorns, in some cases roots, and also hay or fodder produced in other parts of the farm unit. Previously a shepherd guided the livestock; today in most cases fences are used. The livestock is crucial as it contributes to shrub control and soil fertilization. As farms are very large, livestock may circulate between different parcels, depending on the sensitivity and production capacity of the soil.

The trees produce wood, mainly for charcoal, and the cork oaks produce cork, which is at present the most valuable product of the montado. Apart from the fruits, cork and wood, also the shadow is a product of the trees. It is fundamental for the livestock in summer and contributes to the retaining of soil moisture, and thus to the survival of young tree shoots. The stands rejuvenate from their own seed, which asks for a careful management of livestock densities and shrub cleaning. 


\section{Montado}

Amenity, biodiversity, historical information, abiotic regulation
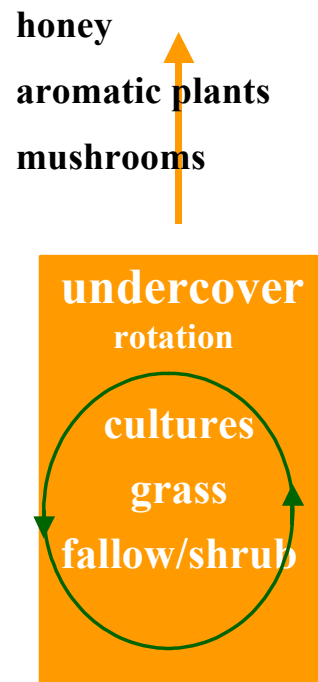

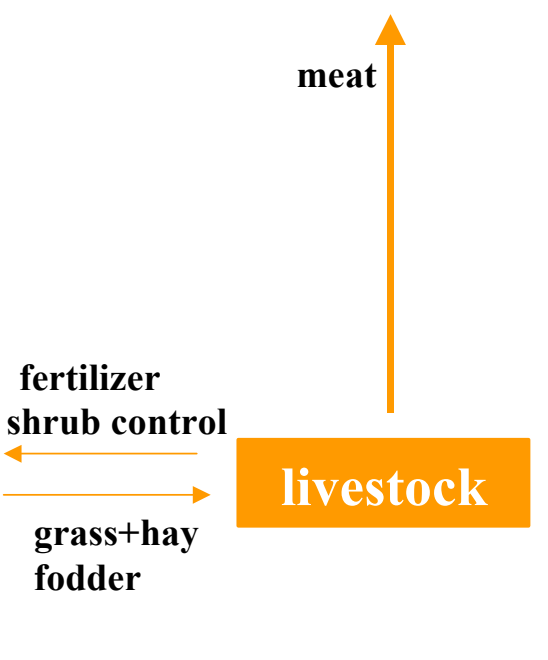

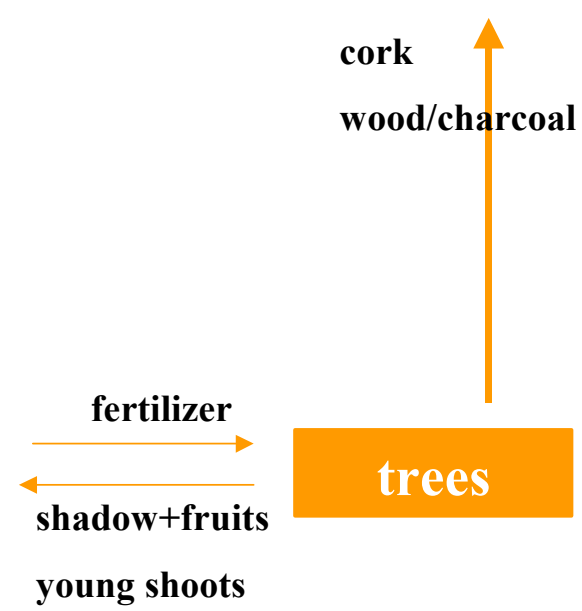

Figure 13. Scheme of the montado land-use system

The montado landscape has many qualities: it has a specific, even unique scenery, closely connected with the regional identity and charged with many cultural values, which support recreation and tourism. Even although similar elements occur over large distances, the variations in tree densities, grazing pressure, rotation, and thus shrub development, still create heterogeneous landscapes. The production is varied and includes many secondary products such as honey, mushrooms and aromatic plants. Due to the extensive use and the diversity in land use and land cover, the biodiversity is high. Multifunctionality at field, farm and landscape level is a main characteristic.

Despite the qualities described above, in the past decades the montado has gone through major changes of both intensification and extensification of land use. The results are a simplification of the landscape, and severe perturbations of the traditional balance between its components. Often the trees were damaged and became vulnerable to diseases and drought, which contributed to increased tree mortality, while natural regeneration was not always maintained. The result has been abandonment followed by a secondary succession with shrub encroachment or the replacement by monospecies plantations of eucalyptus and recently of pines (PintoCorreia and Mascarenhas 1999).

The location and dimension of abandoned or degraded montados, is not known. But it is obvious that the areas prone to abandonment are the most marginal ones, with dryer climates and poorer soils with only holm oaks and vulnerable economies.

In the cork-oak montado the economic viability is in this moment saved by high cork prices. Most landowners thus maintain the system, with livestock breeding as a complement to the cork production, being carefully managed in order not to damage the trees and their natural regeneration. Commercial arable-crop production has practically disappeared, but complete abandonment is rare. The farmers try to keep the system in balance, and thus preserve multifunctionality at field, farm and landscape level. Livestock production on its own is not economically viable, unless it 
is intensified, which would cause strong perturbations of the system. There are no EU supports for the landowners as cork production is profitable enough.

In the holm-oak montado the situation is different, since the cork income is lacking and the decreasing importance of the oaks results in less care for the system balance (Pinto-Correia and Mascarenhas 1999). Compared with the cork oak, the holm oak is better for livestock production, since its acorns are sweeter and have more nutrients. Here too, both extensification and intensifications occur, but the main threats are the degradation of the tree cover and abandonment of the land. One of the EU agri-environmental schemes aims specifically at the maintenance of natural pastures and thus at shrub control, also in montados. This measure is very popular, but as it mainly aims at shrub clearing, it has resulted in a too aggressive and careless cleaning of many abandoned montados, with as a result the further degradation of the tree cover.

In the holm-oak montado the trend of landscape simplification predominates. Only few farmers have been successful in maintaining the system by a specialized livestock production, but this is mainly the case in farms with other incomes, for instance from cork.

\section{How are the targeted instruments working?}

All landscapes discussed above are acknowledged nowadays as valuable because of their natural and cultural qualities. They strongly contribute to regional and European identities. Most of them are in some way included in EU Common Agricultural Policy agri-environmental schemes, but there are many fundamental limitations in this approach.

The small-scale hamlet landscapes of Northeastern Portugal illustrate some of these limitations very well. The measures focus here on the maintenance of the lameiros and on the preservation of the autochthonous breeds. But in doing so, in the same time the commons and the fields are abandoned. Moreover, socio-cultural factors are not considered. It is impossible to keep the livestock and related farm structures with young part-time farmers from distant urban areas. The most isolated villages seem simply not attractive enough to hold people. Even if they aim at the whole system, economic incentives are not enough. Similar arguments hold for the high-mountain landscapes and the chestnut landscapes.

Also for the montados there are various EU agri-environmental measures: as far as holm-oak montado is concerned, for forage systems, and for the keeping of autochthonous breeds. EU measures also exist for olive groves, like those in Tuscany. Moreover, it is possible to receive EU support for higher tree densities in forests and plantations, for the transformation of coppice into high forest or vice versa, for the planting of new stands and for improving forest management, especially with indigenous species. The latter applies e.g. to holm oaks, cork oaks and chestnuts.

For the cork-oak montado, there is no specific measure, since the cork income justifies at this moment the farmers' care of the system. In general this proves to be true in practice. Similar arguments account for all other landscapes with a profitable land use, such as industrial vineyards like those in the Chianti, Montalbano and Vald'Arno in Italy; the decisive criterion is income.

In the holm-oak montado, the clearing of shrubs is supported. If this is done too radically, with damage of trees and increased soil erosion, the measure is counterproductive (Pinto-Correia and Mascarenhas 1999). More subsidies are given to holm-oak stands with pig grazing, but not enough to support the introduction of new 
pig breeds on farms that already stopped with pigs. Especially on holm-oak montados, the support for autochthonous cattle often resulted in too high densities. This has the risks of a reduced natural regeneration of the trees and of soil damage. On the other hand, measures for forage production are ineffective if they cannot be applied due to high tree densities.

In general, it appears that the existing EU agri-environmental measures are frequently applied. But they have several restrictions: they are either confined to just components or specific productions, and they are used as an income support without weighting environmental arguments (Eden and Vieira 2000; Schramek et al. 1999). In fact, the potential for integrated environmental and socio-economic developments has not been used (Eden and Vieira 2000). After all, the application of the existing measures may even cause, or increase, serious landscape degradation.

Also autonomous developments with limited purposes, but with economic perspectives, may disrupt the traditional land use. There are no means to stop them. Where traditional land-use systems nevertheless are maintained, socio-economic or conservation measures are in many cases not decisive factors. Cultural and emotional arguments are at least equally important.

\section{Perspectives for the future}

In many cases the described rural landscapes offer a broad variety of functions that nowadays are much more valued than the agricultural production itself. Although Mediterranean Europe was rich of highly valued cultural landscapes, not so many of them will offer similar qualities in the future if today's trends will continue. Decisionmakers at various levels seem to be aware of both qualities and threats of many of these landscapes, and there are several examples of integrated developments. Most of them are linked to EU instruments, such as the integrated zonal plan for Castro Verde (Portugal), which combines planning and conservation instruments. It considers the whole land-use system and is supported in various ways, although mainly through measures within the agri-environmental scheme. A completely different example, much more focused on private initiatives, is the integrated management approach for the Chianti landscapes by Baldeschi (2000), which won the first Mediterranean Landscape Price (Junta de Andalucia 2001). Other examples are the 'local operations' in some marginalizing regions in France by applying mainly vertical measures within the Agri-environmental Programme (Buller and Brives 2000; Jollivet 1997). Several approaches are limited to conservation areas, predominantly natural parks or even to landscape museums, such as the Ecomuseo del Casentino and the Museo del Paesaggio Storico dell'Apennino in Moscheta (Tuscany).

However, no national or EU plans are foreseen for the persistence or a balanced change of most of the discussed landscapes; let alone real integrated plans. Existing instruments fail to preserve them, or proceed with changes based on specific choices, as they do not allow tailor-made solutions. This happens partly because they are based on other landscapes. Moreover, the instruments for different sectors seem to be difficult to integrate, such as those aiming at public services essential to keep people in the countryside (health, education, transport network, culture).

Although studies of successful cases may contribute at a technical level to tools for an improved management, they do not suffice. Multi-dimensional approaches are required that deal with the integrated socio-cultural, economic and ecological organization of a society, as this coherence is a condition for the sustainability of many cultural landscapes. New economic activities may be generated by integrating 
different sectoral policies, their objectives and priorities (Eden and Vieira 2000). This asks for tailor-made approaches, which cannot be made without the involvement of local actors.

As it seems impossible to maintain all highly valued traditional landscapes and all their attributes and aspects, prioritization is strongly needed. New measures should enable the identification of different objectives for different landscape types and areas.

And even if most of these traditional landscapes cannot be maintained in the future, as they do not fit in with future societies, the actual demand for multifunctionality justifies that we learn from them. Old strategies and management rules, as well as ancient buildings, walls, canals and hedges may very well combine with new economies and functionalities, or even add the extra dimensions that many recent designs are missing.

\section{References}

Agnoletti, M. (ed.) 2002. Il paesaggio agro-forestale toscano: strumenti per l'analisi, la gestione e la conservazione. ARSIA, Firenze.

Antrop, M., 2000. Background concepts for integrated landscape analysis. Agriculture Ecosystems and Environment, 77 (1/2), 17-28.

Arino, P. and Roque, M.A., 2000. Environmental atlas of the Mediterranean. Fundacio Territori i Paisatge, Barcelona.

Austad, I., 2000. The future of traditional agriculture landscapes: retaining desirable qualities. In: Klijn, J. and Vos, W. eds. From landscape ecology to landscape science. Kluwer Academic Publ., Dordrecht, 43-55.

Baldeschi, P. (ed.) 2000. Il Chianti Fiorentino: un progetto per la tutela del paesaggio. Editori Laterza, Roma.

Baldeschi, P., in preparation. I Paesaggi dell'identità Toscana: Il Montalbano. In: Proceedings International Conference, November 21-22, 2002, Firenze.

Beaufoy, G., Baldock, D. and Clark, J. (eds.), 1994. The nature of farming: low intensity farming systems in nine European countries. IEEP, London.

Beckel, L., 1995. Satellite remote sensing forest atlas of Europe. Justus Perthes Gotha.

Brandt, J. and Vejre, H., 2004. Multifunctional landscapes, motives, concepts and perceptions. In: Brandt, J. and Vejre, H. eds. Multifunctional landscapes. Vol.1. Theory, values and history. WIT Book Press, Southampton.

Braudel, F., 1966. La Méditerranée et le monde méditerranéen à l'époque de Philippe II. Tome 1: la part du milieu. Librairie Armand Colin, Paris.

Brédy, C., 1998. Gli alpeggi: caratteristiche e peculiarità nel panorama agricolo della regione Valla d'Aosta. In: Poole, A., Pienkowski, M., McCracken, D.I., et al. eds. Mountain livestock farming and EU policy development: proceedings of the fifth European forum on nature conservation and pastoralism, 18-21 September 1996, Cogne, Valle d'Aosta, Italy. European Forum on Nature Conservation and Pastoralism EFNCP, Kindrochaid, 33-37.

Buller, H. and Brives, H., 2000. France: farm production and rural product as key factors influencing agri-environmental policy. In: Buller, H., Wilson, G.A. and Höll, A. eds. Agri-environmental policy in the European Union. Ashgate, Aldershot, 9-30. 
Commission du Châtaignier (ed.) 1951. Semaine internationale du Châtaignier, Septembre 1950. Ecole Nationale des Eaux et Forets, Nancy. Bulletin Technique Châtaignier no. 3.

Council of Europe, 2000. European landscape convention. T-Land (6).

De Sanctis, A., 1997. Applying regulation 2078/92 in the Abruzzo region of Italy. La Cañada (8), 3-4.

Desplanques, H., 1971. L'influence urbaine sur les paysages ruraux en Italie centrale (Ombrie). In: Dussart, F. ed. L'habitat et les paysages ruraux d'Europe: comptes rendus du symposium tenu a Liege du 29 juin au 5 juillet 1969. Université de Liège, Liege, 93-101. Les Congres et Colloques de l'Universite de Liege no. 58.

Dupont, E., 1998. Alpeggio: rapporto tra razze, tipicità del prodotto e ambiente naturale. In: Poole, A., Pienkowski, M., McCracken, D.I., et al. eds. Mountain livestock farming and EU policy development: proceedings of the fifth European forum on nature conservation and pastoralism, 18-21 September 1996, Cogne, Valle d'Aosta, Italy. European Forum on Nature Conservation and Pastoralism EFNCP, Kindrochaid, 38-39.

Eden, P. and Vieira, M., 2000. Portugal: agri-environmental policy and the maintenance of biodiversity-rich extensive farming systems. In: Buller, H., Wilson, G.A. and Höll, A. eds. Agri-environmental policy in the European Union. Ashgate, Aldershot, 203-218.

Fenaroli, L., 1958. Map. In: Giacomini, V. and Fenaroli, L. eds. Conosci l'Italia. Vol. II. La flora. Touring Club Italiano, Milano.

Gran atlas de España, 1989. Planeta-De Agostini, Barcelona.

Green, B. and Vos, W. (eds.), 2001. Threatened landscapes: conserving cultural environments. SPON Press, London.

Grove, A.T. and Rackham, O., 2001. The nature of Mediterranean Europe: an ecological history. Yale University Press, New Haven.

Houston, J.M., 1964. The western Mediterranean world: an introduction to its regional landscapes. Longmans, London.

Joffre, R., Hubert, B. and Meuret, M., 1991. Les systèmes agro-silvo-pastoraux méditerranéens: enjeux et reflexions pour une gestion raisonnée. UNESCO, Paris. Dossier Mab no. 10.

Jollivet, M., 1997. Des campagnes paysannes au rural "vert": naissance d'une ruralité postindustrielle. In: Jollivet, M. ed. Vers un rural postindustriel, rural et environnement dans huit pays Européens. Harmattan, Paris, 77-126.

Junta de Andalucia, 2001. Prix Méditerranéen du paysage, 2000: PMP 2000. Consejería de Obras Públicas y Transportes, Sevilla.

Klijn, J. and Vos, W., 2000. A new identity for landscape ecology in Europe: a research strategy for the next decade. In: Klijn, J. and Vos, W. eds. From landscape ecology to landscape science. Kluwer Academic Publ., Dordrecht, 149-162.

Lambertin, M., 1998. Pastoralism and grasshoppers in a Nardus grassland in the Mercantour National Park, France: using a grazing plan as a tool to regulate biodiversity. In: Poole, A., Pienkowski, M., McCracken, D.I., et al. eds. Mountain livestock farming and EU policy development: proceedings of the fifth European forum on nature conservation and pasturalism, 18-21 September 1996, Cogne, Valle d'Aosta, Italy. European Forum on Nature Conservation and Pastoralism EFNCP, Kindrochaid, 75-83. 
Le Roy Ladurie, E., 1975. Montaillou, village occitan de 1294 à 1324. Editions Gallimard, Paris.

Lima e Santos, J.M., 1996. Expansão e declínio dos bovinos barrosões. In: Pais de Brito, J.P., Baptista, F.O. and Pereira, B.E. eds. $O$ vôo do arado. Museu Nacional de Etnologia, Lisboa, 359-370.

McNeill, J.R., 1992. The mountains of the Mediterranean world: an environmental history. Cambridge University Press, Cambridge.

Megret, A. and Collin, G., 1995. Cultural landscapes in France. In: Von Droste zu Huelshoff, B., Plachter, H. and Rössler, M. eds. Cultural landscapes of universal value: components of a global strategy. Fischer Verlag, Jena, 307315.

Meiggs, R., 1982. Trees and timber in the ancient Mediterranean world. Clarendon Press, Oxford.

Moreno, J.M. and Oechel, W.C., 1995. Anticipated effects of a changing global environment in Mediterranean-type ecosystems. Springer-Verlag, New York.

Naveh, Z., 1991. Mediterranean uplands as anthropogenic perturbation dependent systems and their dynamic conservation management. In: Ravera, O. ed. Terrestrial and aquatic ecosystems, perturbation and recovery. Ellis Horwood, New York, 544-556.

Naveh, Z., 1998. The role of landscape ecology in the Mediterranean. In: PintoCorreia, T. and Cancela de Abreu, M. eds. Challenges for Mediterranean landscape ecology: the future of cultural landscapes - examples from the Alentejo region: proceedings of the 1st national worshop of landscape ecology. Portuguese Association for Landscape Ecology APEP, Montemor-oNovo.

Osterman, O.P., 1994. Management of a mountain natural reserve in France. La Cañada (2), 2.

Petretti, F., 1995. Extensive farming systems in Italy. La Cañada (3), 7-8.

Petretti, F., 1996. The olive-oil economy in the hill and mountain districts of Central Italy. La Cañada (5), 2-3.

Pinto-Correia, T., 1993. Threatened landscape in Alentejo, Portugal: the "montado" and other "agro-silvo-pastoral" systems. Landscape and Urban Planning, 24 $(1 / 4), 43-48$.

Pinto-Correia, T. and Mascarenhas, J., 1999. Contribution to the extensification/intensification debate: new trends in the Portuguese Montado. Landscape and Urban Planning, 46 (1/3), 125-131.

Pires, J.M. and Moreira, N.T., 1995. O subsistema pecuário de bovinicultura na área do Parque Natural de Montesinho. Instituto Politécnico de Bragança IPB, Bragança. Série Estudos.

Poole, A., Pienkowski, M., McCracken, D.I., et al. (eds.), 1998. Mountain livestock farming and EU policy development: proceedings of the fifth European forum on nature conservation and pastoralism, 18-21 September 1996, Cogne, Valle d'Aosta, Italy. European Forum on Nature Conservation and Pastoralism EFNCP, Kindrochaid.

Portela, J., 1996. Regadios tradicionais em Trás-os-Montes. In: Pais de Brito, J.P., Baptista, F.O. and Pereira, B.E. eds. $O$ vôo do arado. Museu Nacional de Etnologia, Lisboa, 371-384.

Povellato, A., 1997. Implementation of regulation 2078/92 in Italy. La Cañada (7), 10-11. 
Povellato, A., 1998. The implemantation of Regulation 2078/92 in Italy. In: Poole, A., Pienkowski, M., McCracken, D.I., et al. eds. Mountain livestock farming and EU policy development: proceedings of the fifth European forum on nature conservation and pastoralism, 18-21 September 1996, Cogne, Valle d'Aosta, Italy. European Forum on Nature Conservation and Pastoralism EFNCP, Kindrochaid, 126-137.

Ribeiro, O., 1991. Portugal, o Mediterrâneo e o Atlântico. 6th edn. Sá da Costa, Lisboa.

Rodrigues, O., 1996. A mudança do espaço rural em zonas marginais: o caso da Terra Fria Transmontana. In: Pais de Brito, J.P., Baptista, F.O. and Pereira, B.E. eds. $O$ vôo do arado. Museu Nacional de Etnologia, Lisboa, 385-396.

Rommel, M.L., 1994. Spanish Galicia: a rural landscape with historically developed problems. In: Bideau, A. and Bethemont, J. eds. L'avenir des paysages ruraux européens: entre gestion des héritages et dynamique du changement: standing European conference for the study of rural landscape, Colloque de Lyon, 9-13 juin 1992. COMCO Édition, Lyon, 143-148.

Schmitz, P., 1938. Die Agrarlandschaft der italienischen Halbinsel in der Zeit vom Ausgange der römischen Republik bis zum Ende des ersten Jahrhunderts unsrer Zeitrechnung. Parey, Berlin. Berichte über Landwirtschaft no. 139.

Schramek, J., Biehl, D., Buller, H., et al. (eds.), 1999. Implementation and effectiveness of agri-environmental schemes established under regulation 2078/92, Frankfurt. Report FAIR 1 CT95-274.

Sereni, E., 1997. History of the Italian agricultural landscape. Translation by R. Burr Litchfield from Storia del paesaggio agrario italiano (1961). Princeton University Press, Princeton.

Steinhauser, F. (ed.) 1970. Climatic atlas of Europe. WMO, Unesco, Genève.

Taborda, V., 1987. Alto Trás-os-Montes: estudio geográfico. 2nd edn. Livros Horizonte, Lisboa.

Thran, P. and Broekhuizen, S., 1965. Agro-climatic atlas of Europe. Pudoc, Wageningen.

Toutain, J., 1968. The economic life of the ancient world. Barnes \& Noble, New York.

Unwin, T., 1994. Changing landscapes of the Minho, Portugal: industrial and touristic influences. In: Bideau, A. and Bethemont, J. eds. L'avenir des paysages ruraux européens: entre gestion des héritages et dynamique du changement: standing European conference for the study of rural landscape, Colloque de Lyon, 9-13 juin 1992. COMCO Édition, Lyon, 157-164.

Valaoras, G. (compiler), 1997. Mediterranean conservation strategy/action plan 1996-2001. WWF Mediterranean Programme Office, Roma.

Vivere nel contado al tempo di Lorenzo, 1992. Centro Di Firenze, Firenze.

Vos, W., Austad, I. and Pinto-Correia, T., 1993. Sustainable forestry in old cultural landscapes in Europe. In: Koch, N.E. ed. The scientific basis for sustainable multiple-use forestry in the European Community: proceedings of a scientific workshop under the Community research programme on agriculture and agro-industry, including fisheries ("AIR"), held in Brussels, Belgium, 28 and 29 June 1993. Commission of the European Communities, Brussels, 81-96.

Vos, W. and Hoogendoorn, J., 2000. Multifunctionality of agriculture and landscape: challenges for innovative research. In: Boekestein, A., Diederen, P., Jongen, W.M.F., et al. eds. Towards an agenda for agricultural research in Europe: proceedings of a conference held in Wageningen, The Netherlands, from 1315 April 1999. Wageningen Pers, Wageningen, 215-223. 
Vos, W. and Klijn, J., 2000. Trends in European landscape development: prospects for a sustainable future. In: Klijn, J. and Vos, W. eds. From landscape ecology to landscape science. Kluwer, Dordrecht, 13-30.

Vos, W. and Stortelder, A., 1992. Vanishing Tuscan landscapes: landscape ecology of a Submediterranean-Montane area (Solano Basin, Tuscany, Italy). Pudoc, Wageningen.

Wascher, D.M. (ed.) 2000. The face of Europe: policy perspectives for European landscapes. European Centre for Nature Conservation ECNC, Tilburg. ECNC Technical Report Series. 